for conservation globally

Threatened

通
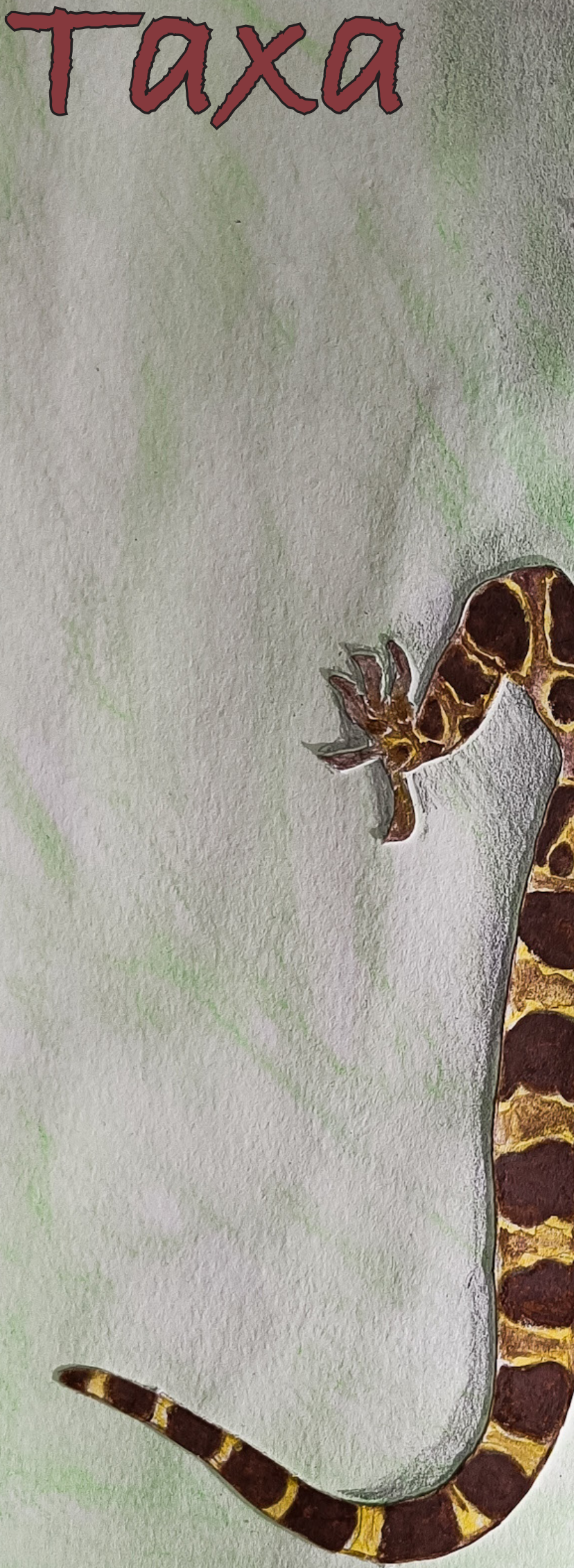

Open Access

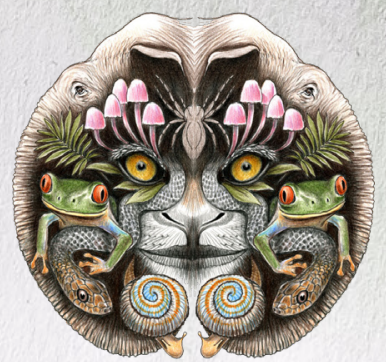

$10.1160 \mathrm{~g} / \mathrm{j}$ ott.2022.14.1.20311-20538 wWw.threatenedtaxa.org

26 January 2022 (Online \& Print) 14(1): 20311-20538 ISSN0974-7907 (Online) ISSN 0974-7893 (Print) 


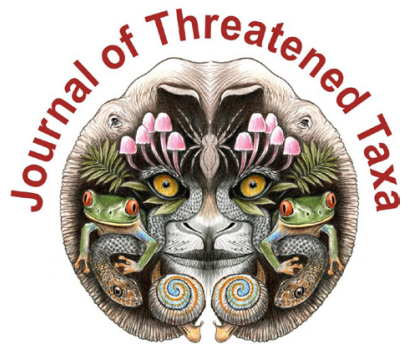

ISSN 0974-7907 (Online); ISSN $0974-7893$ (Print)

Publisher

Host

Wildlife Information Liaison Development Society

www.wild.zooreach.org

Zoo Outreach Organization www.zooreach.org

No. 12, Thiruvannamalai Nagar, Saravanampatti - Kalapatti Road, Saravanampatti, Coimbatore, Tamil Nadu 641035, India

Ph: +91 9385339863 | www.threatenedtaxa.org

Email: sanjay@threatenedtaxa.org

EDITORS

\section{Founder \& Chief Editor}

Dr. Sanjay Molur

Wildlife Information Liaison Development (WILD) Society \& Zoo Outreach Organization (ZOO),

12 Thiruvannamalai Nagar, Saravanampatti, Coimbatore, Tamil Nadu 641035, India

\section{Deputy Chief Editor}

Dr. Neelesh Dahanukar

Noida, Uttar Pradesh, India

\section{Managing Editor}

Mr. B. Ravichandran, WILD/ZOO, Coimbatore, India

\section{Associate Editors}

Dr. Mandar Paingankar, Government Science College Gadchiroli, Maharashtra 442605, India

Dr. Ulrike Streicher, Wildlife Veterinarian, Eugene, Oregon, USA

Ms. Priyanka Iyer, ZOO/WILD, Coimbatore, Tamil Nadu 641035, India

Dr. B.A. Daniel, ZOO/WILD, Coimbatore, Tamil Nadu 641035, India

\section{Editorial Board}

Dr. Russel Mittermeier

Executive Vice Chair, Conservation International, Arlington, Virginia 22202, USA

\section{Prof. Mewa Singh Ph.D., FASc, FNA, FNASc, FNAPsy}

Ramanna Fellow and Life-Long Distinguished Professor, Biopsychology Laboratory, and Institute of Excellence, University of Mysore, Mysuru, Karnataka 570006, India; Honorary Professor, Jawaharlal Nehru Centre for Advanced Scientific Research, Bangalore; and Adjunct Professor, National Institute of Advanced Studies, Bangalore

\section{Stephen D. Nash}

Scientific Illustrator, Conservation International, Dept. of Anatomical Sciences, Health Sciences Center, T-8, Room 045, Stony Brook University, Stony Brook, NY 11794-8081, USA

\section{Dr. Fred Pluthero}

Toronto, Canada

\section{Dr. Priya Davidar}

Sigur Nature Trust, Chadapatti, Mavinhalla PO, Nilgiris, Tamil Nadu 643223, India

\section{Dr. Martin Fisher}

Senior Associate Professor, Battcock Centre for Experimental Astrophysics, Cavendish

Laboratory, JJ Thomson Avenue, Cambridge CB3 OHE, UK

\section{Dr. John Fellowes}

Honorary Assistant Professor, The Kadoorie Institute, 8/F, T.T. Tsui Building, The University of Hong Kong, Pokfulam Road, Hong Kong

\section{Prof. Dr. Mirco Solé}

Universidade Estadual de Santa Cruz, Departamento de Ciências Biológicas, Vice-coordenado do Programa de Pós-Graduação em Zoologia, Rodovia Ilhéus/Itabuna, Km 16 (45662-000)

Salobrinho, Ilhéus - Bahia - Brasil

\section{Dr. Rajeev Raghavan}

Professor of Taxonomy, Kerala University of Fisheries \& Ocean Studies, Kochi, Kerala, India

\section{English Editors}

Mrs. Mira Bhojwani, Pune, India

Dr. Fred Pluthero, Toronto, Canad

Mr. P. Ilangovan, Chennai, India

Web Development

Mrs. Latha G. Ravikumar, ZOO/WILD, Coimbatore, India

\section{Typesetting}

Mr. Arul Jagadish, ZOO, Coimbatore, India

Mrs. Radhika, ZOO, Coimbatore, India

Mrs. Geetha, ZOO, Coimbatore India
Fundraising/Communications

Mrs. Payal B. Molur, Coimbatore, India

Subject Editors 2018-2020

Fungi

Dr. B. Shivaraju, Bengaluru, Karnataka, India

Dr. R.K. Verma, Tropical Forest Research Institute, Jabalpur, India

Dr. Vatsavaya S. Raju, Kakatiay University, Warangal, Andhra Pradesh, India

Dr. M. Krishnappa, Jnana Sahyadri, Kuvempu University, Shimoga, Karnataka, India

Dr. K.R. Sridhar, Mangalore University, Mangalagangotri, Mangalore, Karnataka, India

Dr. Gunjan Biswas, Vidyasagar University, Midnapore, West Bengal, India

\section{Plants}

Dr. G.P. Sinha, Botanical Survey of India, Allahabad, India

Dr. N.P. Balakrishnan, Ret. Joint Director, BSI, Coimbatore, India

Dr. Shonil Bhagwat, Open University and University of Oxford, UK

Prof. D.J. Bhat, Retd. Professor, Goa University, Goa, India

Dr. Ferdinando Boero, Università del Salento, Lecce, Italy

Dr. Dale R. Calder, Royal Ontaro Museum, Toronto, Ontario, Canada

Dr. Cleofas Cervancia, Univ. of Philippines Los Baños College Laguna, Philippines

Dr. F.B. Vincent Florens, University of Mauritius, Mauritius

Dr. Merlin Franco, Curtin University, Malaysia

Dr. V. Irudayaraj, St. Xavier's College, Palayamkottai, Tamil Nadu, India

Dr. B.S. Kholia, Botanical Survey of India, Gangtok, Sikkim, India

Dr. Pankaj Kumar, Kadoorie Farm and Botanic Garden Corporation, Hong Kong S.A.R., China

Dr. V. Sampath Kumar, Botanical Survey of India, Howrah, West Bengal, India

Dr. A.J. Solomon Raju, Andhra University, Visakhapatnam, India

Dr. Vijayasankar Raman, University of Mississippi, USA

Dr. B. Ravi Prasad Rao, Sri Krishnadevaraya University, Anantpur, India

Dr. K. Ravikumar, FRLHT, Bengaluru, Karnataka, India

Dr. Aparna Watve, Pune, Maharashtra, India

Dr. Qiang Liu, Xishuangbanna Tropical Botanical Garden, Yunnan, China

Dr. Noor Azhar Mohamed Shazili, Universiti Malaysia Terengganu, Kuala Terengganu, Malaysia

Dr. M.K. Vasudeva Rao, Shiv Ranjani Housing Society, Pune, Maharashtra, India

Prof. A.J. Solomon Raju, Andhra University, Visakhapatnam, India

Dr. Mandar Datar, Agharkar Research Institute, Pune, Maharashtra, India

Dr. M.K. Janarthanam, Goa University, Goa, India

Dr. K. Karthigeyan, Botanical Survey of India, India

Dr. Errol Vela, University of Montpellier, Montpellier, France

Dr. P. Lakshminarasimhan, Botanical Survey of India, Howrah, India

Dr. Larry R. Noblick, Montgomery Botanical Center, Miami, USA

Dr. K. Haridasan, Pallavur, Palakkad District, Kerala, India

Dr. Analinda Manila-Fajard, University of the Philippines Los Banos, Laguna, Philippines

Dr. P.A. Sinu, Central University of Kerala, Kasaragod, Kerala, India

Dr. Afroz Alam, Banasthali Vidyapith (accredited A grade by NAAC), Rajasthan, India

Dr. K.P. Rajesh, Zamorin's Guruvayurappan College, GA College PO, Kozhikode, Kerala, India

Dr. David E. Boufford, Harvard University Herbaria, Cambridge, MA 02138-2020, USA

Dr. Ritesh Kumar Choudhary, Agharkar Research Institute, Pune, Maharashtra, India

Dr. Navendu Page, Wildlife Institute of India, Chandrabani, Dehradun, Uttarakhand, India

\section{Invertebrates}

Dr. R.K. Avasthi, Rohtak University, Haryana, India

Dr. D.B. Bastawade, Maharashtra, India

Dr. Partha Pratim Bhattacharjee, Tripura University, Suryamaninagar, India

Dr. Kailash Chandra, Zoological Survey of India, Jabalpur, Madhya Pradesh, India

Dr. Ansie Dippenaar-Schoeman, University of Pretoria, Queenswood, South Africa

Dr. Rory Dow, National Museum of natural History Naturalis, The Netherlands

Dr. Brian Fisher, California Academy of Sciences, USA

Dr. Richard Gallon, llandudno, North Wales, LL30 1UP

Dr. Hemant V. Ghate, Modern College, Pune, India

Dr. M. Monwar Hossain, Jahangirnagar University, Dhaka, Bangladesh

Mr. Jatishwor Singh Irungbam, Biology Centre CAS, Branišovská, Czech Republic.

Dr. Ian J. Kitching, Natural History Museum, Cromwell Road, UK

Dr. George Mathew, Kerala Forest Research Institute, Peechi, India

For Focus, Scope, Aims, and Policies, visit https://threatenedtaxa.org/index.php/JoTT/aims_scope
For Article Submission Guidelines, visit https://threatenedtaxa.org/index.php/JoTT/about/submissions
For Policies against Scientific Misconduct, visit https://threatenedtaxa.org/index.php/JoTT/policies_various

continued on the back inside cover 


\title{
Associations of butterflies across different forest types in Uttarakhand, western Himalaya, India: implications for conservation planning
}

\author{
Arun Pratap Singh (D) \\ Entomology Branch, Forest Research Institute, Chakarata Road, P.O. New Forest, Dehradun, Uttarakhand 248006, India. \\ ranoteaps@gmail.com
}

\begin{abstract}
Champion \& Seth classified Indian forests into different 'forest types and sub-types', based on similarity of dominant vegetation and structural arrangement of species in each. However, it is not known if the species composition and community structure of butterflies is also different in each forest sub-type. If this is the case then each forest sub-type harbouring unique species can be taken as units of conservation on a sub-regional scale. The present study assesses for the first time the species composition and community structure of butterflies across 20 different and prominent 'forest sub-types' found across the state of Uttarakhand, western Himalaya. Data collected over eight years (2006-2009; June 2012; 2017-2020) using random seasonal sampling covering 307 transects revealed 370 butterfly taxa. Hierarchical clustering of butterfly abundances revealed seven different butterfly communities spread over 19 forest subtypes. Of these four forest sub-types (3C/C2a moist Shiwalik sal forest; 12/C2c moist temperate deciduous forest; 12/C1a ban oak forest; \& 3C/C2c moist Terai sal forest) were identified as most important as they hold most of the butterfly diversity of the state including 58 rare taxa identified according to 'rarity' out of the total. GIS based mapping of these 58 priority species over laid on the protected area network and forest cover distribution in the state revealed many forested sites outside the PA network supporting these rare taxa. These sites along a physiogeographical gradient with important forest sub-types and rare taxa can be recommended and listed as new sites for conservation in the state.
\end{abstract}

Keywords: Ban Oak, butterfly, protected area network, physiogeography, rarity, tropical moist deciduous forest, vegetation.

Citation: Singh, A.P. (2022). Associations of butterflies across different forest types in Uttarakhand, western Himalaya, India: implications for conservation planning. Journal of Threatened Taxa 14(1): 20346-20370. https://doi.org/10.11609/jott.7711.14.1.20346-20370

Copyright: (c) Singh 2022. Creative Commons Attribution 4.0 International License. JoTT allows unrestricted use, reproduction, and distribution of this article in any medium by providing adequate credit to the author(s) and the source of publication.

Funding: Indian Council of Forestry Research \& Education (ICFRE), Dehradun.

Competing interests: The author declares no competing interests.

Author details: ARUN PRATAP SINGH is currently working as a scientist with the Forest Research Institute, Dehradun. His experience pertains to the conservation and ecology of butterflies and birds across the Himalayan region over the last three decades.

Acknowledgements: The data used in the present study was is part of the ICFRE funded projects carried out by the author entitled "Butterflies associated with major forest types/sub-types in Uttarakhand" (No: FRI-627/FED-44; 2017-2021 and "Butterfly diversity in moist temperate Ban oak forests of Garhwal" (No. FRI-348/FED-23; 2006-2009) along with a 10 day self funded survey conducted in Kedarnath Wildlife Sanctuary during June2012. The author is thankful to the, Director General, Indian Council of Forestry Research and Education, (ICFRE), Dehradun for providing necessary funding for the projects. Thanks are due to the Director, Forest Research Institute (FRI) and Head, Forest Entomology, Forest Protection Division, for providing the necessary facilities. I would like to thank Tribhuwan Singh (JPF) and Rohit Kumar (FA),Forest Protection Division,FRI, for assisting the PI in collection and compilation of data and generating GIS maps. Help of Praveen Verma and H.B.Naithani, plant taxonomists, Botany Division, FRI is also duly acknowledged in identification of plant specimens associated different forest sub-types. Lastly, I would also like to thank the Chief Wildlife Warden, Uttarakhand Forest Department and various Divisional Forest Officers of the state and their field staff for providing logistical support during field surveys, from time to time.

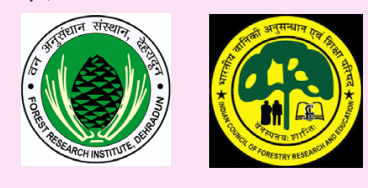




\section{INTRODUCTION}

Butterflies, amongst invertebrates, are suitable indicators for ecological studies (Lomov et al. 2006), as the taxonomy, geographical distribution and status of many species are relatively well known (Pollard 1977; Thomas 1983; Thomas \& Mallorie 1985; Murphy \& Wilcox 1986). They are phytophagous, primary herbivores, good pollinators and surrogates plant diversity living close by their food plants (Ehrlich \& Raven 1964; Gilbert \& Smiley 1978; Pyle 1980). The precise and restricted environmental requirements of particular butterflies make them of considerable value as a group of indicator taxa that indicate the broader effects of environmental changes or reflects a particular suite of ecological conditions or habitat heterogeneity (Pyle 1980; Gilbert 1980, 1984; Brown 1982; Rosenberg et al. 1986; Murphy et al. 1990; New 1991; Kermen 1992; Pearman et al. 1995). Strong association with vegetation structure and composition makes Lepidoptera a particularly useful bioindicator for monitoring eco-restoration programs (Kremen et al. 1993; New et al. 1995).

Habitat is an important requisite for the proliferation and conservation of a butterfly species (Gilbert \& Singer 1975), as species prefer particular habitats, closely related to their life history, breeding, larval and adult food resources and destruction of forest severely affects species habitats (Wells et al. 1983) and many species which were once common become rare. Thus, identification and conservation of priority landscapes, is very important. Champion \& Seth (1968) classified Indian forests into different 'forest types' their sub units as 'forest sub-types', based on the similarity of dominant vegetation and structural arrangement of species within each of them, i.e., 'IV montane temperate forest' is one of VI major "forest types" found across India (other 5 categories being "I. moist tropical forests, II. dry tropical forests; III montane subtropical forests; V sub-alpine forests, and VI alpine forests" classified by Champion \& Seth (1968)), while its lowest unit in the hierarchy is a 'sub-type', e.g., " $12 \mathrm{C}_{1} / 1 a$ Ban oak forest" (Here, '12' signifies "12 Himalayan moist temperate forest" in a group of three [the other two being 11 Montane wet temperate forests \& 13 Himalayan dry temperate forests). Then further sub-division of this sub-group " 12 " into three groups: $C_{1}-C_{3}$, where " $C_{1}$ " signifies " $C_{1}$ lower western Himalayan temperate forest" (other 2 being " $C_{2}$ upper west Himalayan temperate forest" and " $C_{3}$ east Himalayan temperate forest") and lastly its last subdivision which is depicted as "1a", i.e., "1a Ban oak forest (Q. incana)" (Quercus incana $=Q$. leucotrichophora) amongst the set of two (the other being " $1 b$ Moru oak forest ( $Q$. dialata)" (Quercus dilatata $=Q$. floribunda) (Champion \& Seth 1968)]. In this way, different 'forest subtypes' have been classified and labelled in India.

However, it is not known if the species composition and community structure of lower groups of animals such as butterflies are also different within each 'forest-subtype' or each have a unique community of butterflies. If this is the case then each forest sub-type harbouring unique and rare species can be taken as a unit of conservation on a sub-regional scale (western Himalaya) or state level (Uttarakhand). In this study we tried to evaluate and examine potential 'forest sub-types' or 'a group of forest sub-types' that have unique butterfly diversity which can be taken up as units of conservation of biodiversity at the state level. Besides, this can also be helpful in identification of new conservation areas with forest habitats outside the PA network and thus fill gaps in their connectivity, in the state. The rationale behind this is that many butterfly species are restricted to forested habitats in the state, have geographical distribution spread across the Himalayan region, i.e., western, central, and eastern Himalaya along a wide altitudinal gradient, e.g., Pale Green Sailer Neptis zaida zaida Doubleday, [1848] or Broad-banded Sailer, $N$. sankara sankara (Kollar, [1844]) (Nymphalidae) both occur in the state between 800-2,500 m, as observed in the present study. Fragmentation of their forested habitats on a larger spatial and temporal scale, may lead to isolated populations, local extinctions that can significantly affect their distribution, as they do not migrate. Thus, gaps and connectivity of the protected areas needs to be maintained for long term conservation.

\section{STUDY AREA}

The study was carried out in Uttarakhand state of India which covers an area of $53,483 \mathrm{~km}^{2}$, which is $1.63 \%$ of the geographical area of the country, and lies between 28.716-31.466 N latitude \& 77.566-81.05 E longitude. This predominantly mountainous state, shares its borders with Himachal Pradesh to the west and Uttar Pradesh to the south. It also shares international borders with Nepal in the east and China (Tibet) to the north. The state is mainly representative of the western Himalaya, the climate and vegetation vary greatly with altitude, from glaciers at the highest elevations, and temperate to subtropical at the lower elevations. Nanda Devi peak is the highest point at 7,816 $\mathrm{m}$ in the state while the lowest areas at $\sim 100 \mathrm{~m}$ lie in the Terai grasslands. 


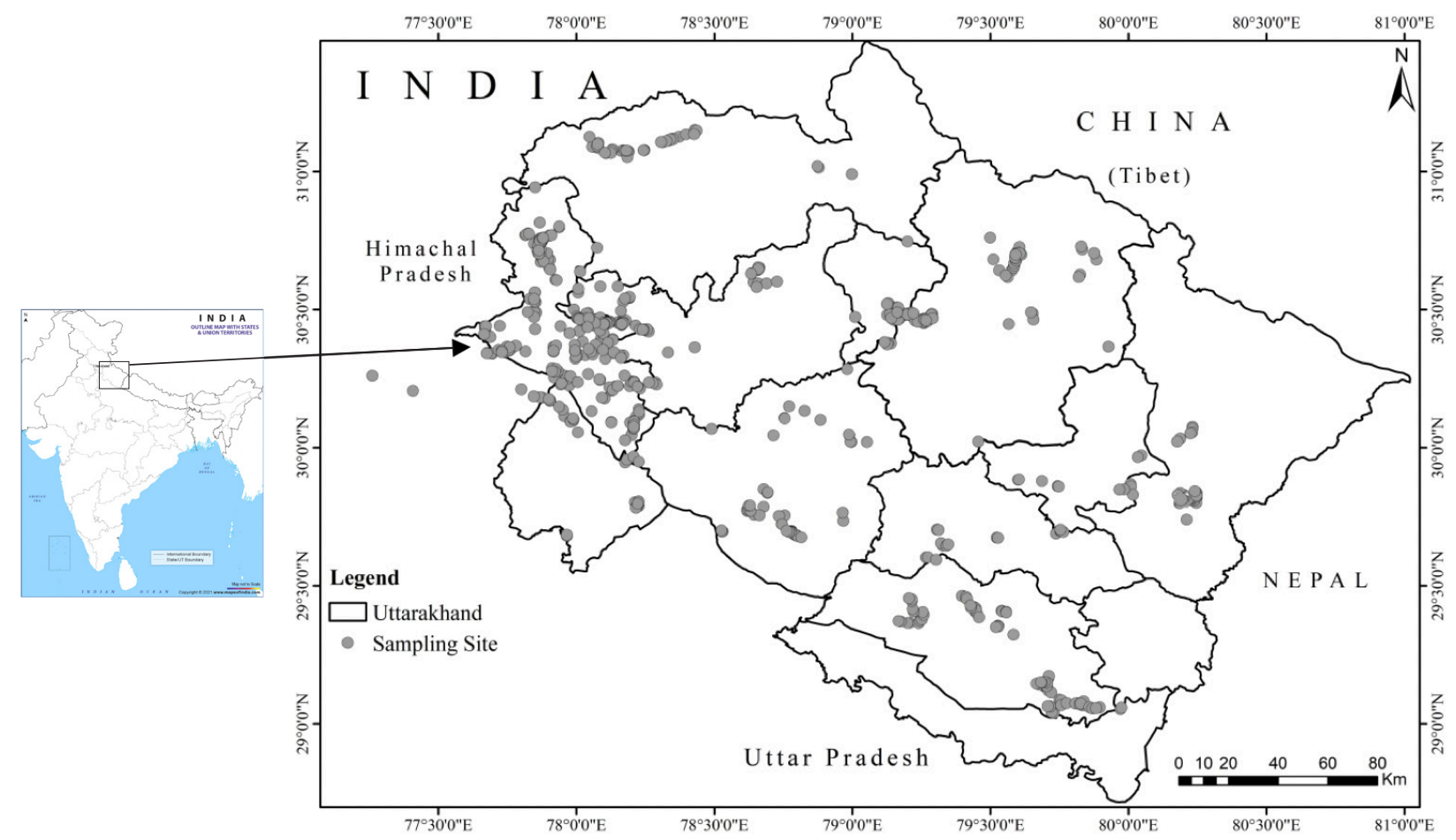

Figure 1. GPS locations of sampling sites for study on butterflies undertaken during 2006-2009, June 2012 \& $2017-2020$ in Uttarakhand state of India.

The average annual rainfall is $1,500 \mathrm{~mm}$ and the annual temperature varies from below $0^{\circ} \mathrm{C}$ to $43^{\circ} \mathrm{C}$. Major rivers, Ganga, Yamuna, Ramganga, \& Sharda, drain the state along with their tributaries. The Himalayan range in Uttarakhand is divided into the distinct non-montane and montane physiographic zones. The lower zone comprises the 'Bhabhar' region in non-montane lowland woodlands having Gangetic moist deciduous forests and the Terai region (below $500 \mathrm{~m}$ ) running parallel to it, which comprises mainly the marshes and grasslands (Botanical Survey of India 2021). The montane region is divided into sub-Himalaya, which consists of the Shiwalik ranges, the lower Himalayan ranges, and the Doon (flat long valleys) lying north of the Shiwaliks ( 500-1,000 m). Above this region are the lesser Himalaya ( 1,000-3,000 m) followed mid Himalaya ( 3,0004,000 m) and then greater Himalaya ( 4,000-6,000 m) (Khanduri et al. 2013) and the trans-Himalaya (above $5,000 \mathrm{~m}$ ), also known as the Tethys Himalayas and the Indo-Tibet plateau, the region is in the rain shadow area that transforms into the cold desert.

Forests cover an area of $24,303.04 \mathrm{~km}^{2}$ in the state, which constitutes $45.44 \%$ of the state's geographical area (FSI 2019). The state is represented by biogeographic zone 2B western Himalaya and 7B Shiwaliks of India (Rodgers \& Pawar 1988). The state is rich in biodiversity having about 102 species of mammals, 692 birds (https://ebird.org/region/IN-UL), 13 amphibians \& 53 reptiles (Vasudevan \& Sondhi 2010), and 124 fishes (https://forest.uk.gov.in/wildlife-management). Some of the globally endangered fauna like the Asiatic Elephant Elephas maximus, Snow Leopard Panthera uncia, Tiger Panthera tigris, Leopard Panthera pardus, Musk Deer Moschus chrysogaster, Swamp Deer Rucervus duvaucelii, Cheer Pheasant Catreus wallichii, and the King Cobra Ophiophagus hannah are found in the state. Uttarakhand shelters around 4,000 species of plants, belonging to 1,198 genera, under 192 families, of which 34 species have been listed as threatened (Nayar \& Sastry 1987, 1988, 1990; https://indiabiodiversity.org/). The PA network cover 12 percent of the total geographical area of the state, which includes six national parks, seven wildlife sanctuaries, four conservation reserves, and one biosphere reserve (Appendix 1).

\section{Previous studies on butterflies in Uttarakhand}

Studies on natural history and checklists of different areas in Uttarakhand state have been carried out as early as 1886 (Doherty 1886; Mackinnon \& de Nicéville 1899; Hannyngton 1910-11; Ollenbach 1930; Shull 1958, 1962; Baindur 1993; Smetacek 2002, 2004, 2012; Bhardwaj et al. 2012; Bhardwaj \& Uniyal 2013; Singh \& 
Bhandari 2003, 2006; Singh \& Sondhi 2016; Verma \& Arya 2018; Sondhi \& Kunte 2018; Singh \& Singh 2021) and the total number of butterfly species recorded in the state so far is $~ 500$ species, based on these records. However, none of these studies give an account on the association of butterfly species with different forest sub-types as classified by Champion \& Seth (1968), found across the state of Uttarakhand. The author had earlier studied butterfly-forest type associations in 11 major "forest sub-types" in the state of Arunachal Pradesh (eastern Himalaya), India (Singh 2017) and identified four forest sub-types: 2B/1S1 sub-Himalayan light alluvial plains semi-evergreen forests; $2 \mathrm{~B} / \mathrm{C} 1 \mathrm{a}$ Assam alluvial plains semi-evergreen forests; $2 \mathrm{~B} / 2 \mathrm{~S} 2$ eastern alluvial secondary semi-evergreen forests, and 3/1S2 b Terminalia-Duabanga as major forest sub-types supporting 415 butterfly taxa along with many rare and endemic species in the northeastern region and eastern Himalaya, but the forest sub-types occurring in these two Himalayan states are totally different from each other.

\section{METHODS}

Random sampling surveys were carried out for eight years under two different projects (2006-2009 and 2017-2020, respectively) across 11 districts of Uttarakhand state covering all the six butterfly seasons (spring, summer, pre-monsoon, monsoon, postmonsoon, autumn, and winter; Smith 1989) of the year. Surveys were carried out using 'Pollard Walk' on the line transects (Pollard \& Yates 1993). Sampling on each transect (ca. $1 \mathrm{~km}$ ) was done and butterflies were observed up to $20 \mathrm{~m}$ on both the sides of the trail for $1 \mathrm{~h}$ in a stretch between $1000 \mathrm{~h}$ and $1600 \mathrm{~h}$ to collect data on individual butterfly species abundance. Each sampling survey was carried out by the author, while 1-2 helpers were also used for recording data, collection of insect and plant material from time to time. Coordinates of all the locations for 307 samplings carried out were recorded using a GPS (Etrex Garmin Vista) (Figure 1) covering 20 major forest sub-types (FSI 2011; Figure 2 \& Appendix ii) existing across the state of Uttarakhand.

Identification and distribution range of each taxa was assessed based on published literature (Moore 1874, 1890-1992, 1893-1896, 1896-1899, 1899-1900, 1901-1903, 1903-1905; Swinhoe 1905-1910, 19101911, 1911-1912 \& 1912-1913; Bingham 1905; Talbot 1939, 1947; Evans 1932; Wynter-Blyth 1957; D’Abrera 1982, 1985, 1986; Haribal 1992; Smith 1989, 2006;
Kehimkar 2008, 2016; Singh 2011; Smetacek 2015; Gasse 2017; Sondhi \& Kunte 2018) and websites (http:// www.ifoundbutterflies.org/ and http://flutters.org/). Comparison of a few specimens was also done with specimens at the National Forest Insect Collection (NFIC) at Forest Research Institute, Dehradun, Uttarakhand, India, for identification.

Dominant vegetation (mainly trees $\&$ shrubs) in the respective forest sub-types were also identified and confirmed by ground truthing by laying down $10 \times 10$ $\mathrm{m}$ quadrates, collected plant material and preparing herbariums. Photographs and herbarium specimens were identified in the field and many were identified and confirmed from plant taxonomists based at Systematic Botany Branch, Botany Division, FRI, Dehradun and literature (Brandis 1906; Rai et al. 2017; http://www. gbif.org).

\section{Evaluating species of conservation priority: rarity analysis of butterflies}

The degree of 'rarity' characterizing a species is usually an indicator of extinction risk (Rabnowitz et al. 1986; Pimm et al. 1988; Arita et al. 1990; Primarck 1993; Gaston 1994; Brown 1995; Gaston \& Blackburn 1995) and provides a basis to identify threatened species (Rabinowitz 1981; Arita et al. 1990; Daniels et al. 1991; Berg \& Tjernberg 1996). In general, species characterized by small geographic range, habitat specialization, and low abundance, are at higher risk of extinction than a widely distributed, habitat generalist and with high abundance. Rabinowitz et al. (1986) have examined types of rarity, and in what important ways rare species differ from one another. They first distinguish three traits, characteristic of all taxa recorded: (i) Geographical range - whether a species occurs over a broad area or whether it is endemic to a particular area; (ii) Habitat specificity - the degree to which a species occurs in a variety of biotopes' or 'habitats' is restricted to one or a few specialized sites versus generalists; and (iii) Local population size - whether a species occurs in large populations somewhere within range or has small populations whenever it is found.

In the present study, Rabinowitz et al. (1986) classification of rarity based on the three above traits was used. Only those species were filtered out the total as rare which had: (i) narrow geographical range, i.e., those species which had narrow distribution restricted only to western and central Himalaya as against those with wide distribution, i.e., Himalaya, northeastern India, \& Peninsular India; (ii) restricted to two or less forest sub-types as against more than two forest sub- 


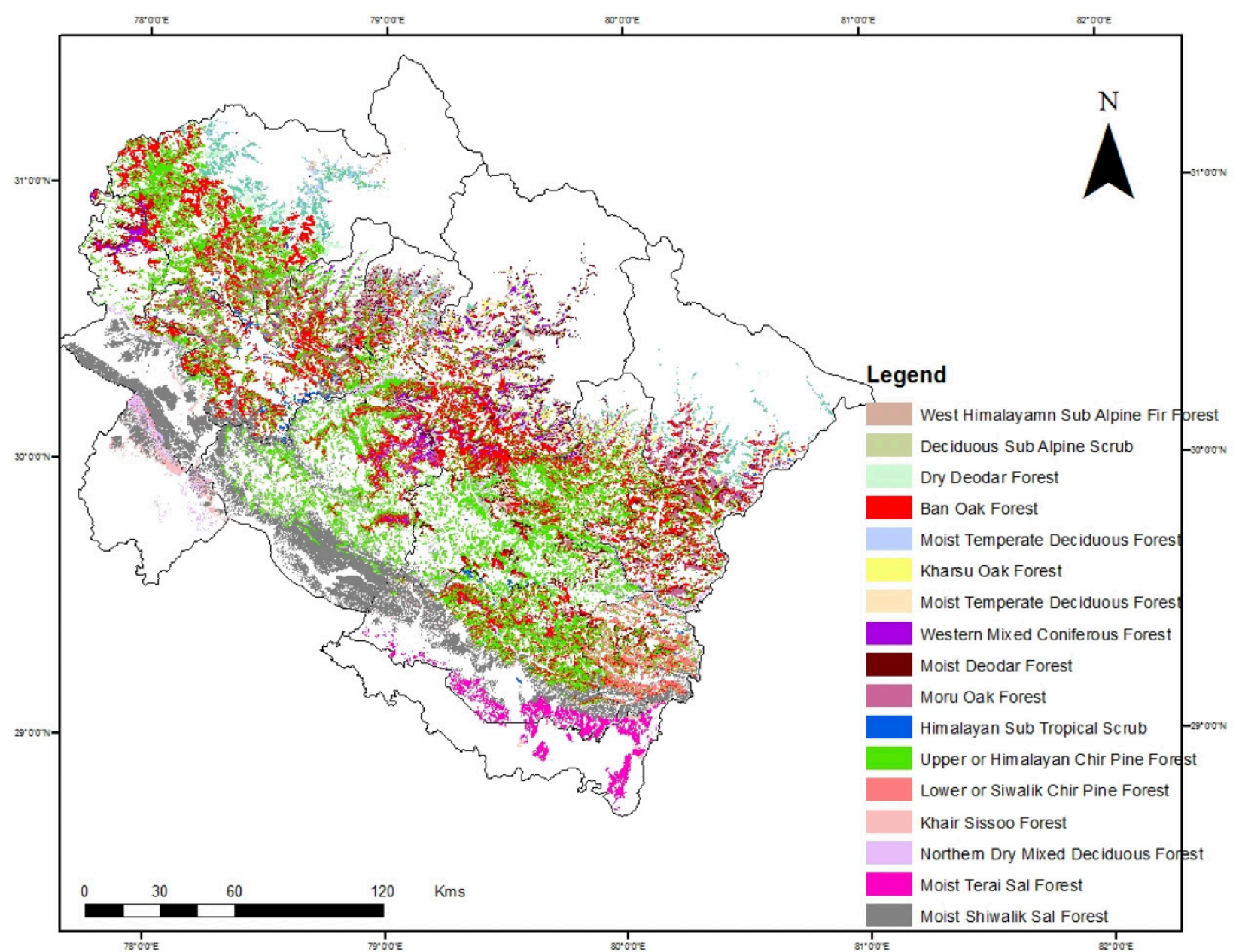

Figure 2. Distribution of major forest types surveyed in Uttarakhand.

types; and (iii) having small local population size across their distribution range, i.e., those taxa which were classified as 'very rare', 'rare', and 'not rare' by Evans (1932) and Kehimkar (2008), as against 'fairly common', 'common', and 'very common'.

Hierarchical clustering of different forest sub-types based on butterfly species distribution and relative abundance.

The data of relative abundance of all the species of butterflies sampled against 20 different forest subtypes was pooled and averaged to relative abundance per sampling in each of the forest sub-type to remove varied sampling bias and was done using statistical software "NCSS Data Analysis 2021, v21.0.2", to know the dissimilarly of forest sub-types in terms of butterfly species composition.

\section{RESULTS AND DISCUSSION}

The field surveys revealed 370 butterfly taxa (Papilionidae (31); Pieridae (32); Nymphalidae(138); Lycaenidae (97); Hesperiidae (62) and Riodinidae (7); see appendix.iii), which accounted to ca $75 \%$ of the species recorded from the state so far. If we exclude $\sim 40$ historic records (Singh \& Sondhi 2016; Sondhi \& Kunte 2018 ), then it totals to $80 \%$ of the total species found in the state. The study also reported new range extensions from central and eastern Himalaya, i.e., Dark Sapphire (Singh \& Seal 2019); Scarce Lilacfork Lethe dura gammiei (Moore, [1892]) (Singh \& Singh 2019), Dubious Five ring Ypthima parasakra parasakra Eliot, 1987 (Singh \& Singh 2022) and records like White-ringed Meadowbrown, Hyponephele davendra davendra (Moore, 1865) (Singh \& Singh 2021), Pale Jezebel Delias sanaca sanaca (Moore, [1858]) (Singh 2016); Mountain Tortoiseshell Aglais rizana (Moore, 1872) (Singh \& Singh 2019); White-wedged Woodbrown Lethe dakwania Tytler, 1939 


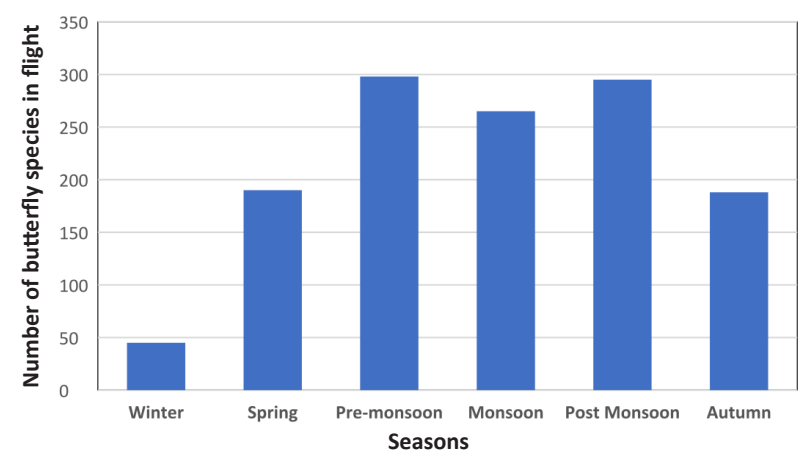

Figure 3. Seasonality of butterflies in Uttarakhand.
(Singh \& Singh 2021), to the state. Some rare records like Garhwal Swordtail Graphium garhwalica (Katayama, 1988), Highbrown Silverspot, Argynnis jainadeva jainadeva Moore, 1864; Regal Apollo, Parnassius charltonius Gray, [1853] and new range extensions (Redtailed Forester, Lethe sinorix sinorix (Hewitson, [1863]) and Nepal Comma Polygonia c-album cognata Moore, [1899]) are reported in this paper.

The relative abundance of species ranged 1-1,596 individuals. These species were then ranked into four abundance classes based on their quartile division, i.e.,

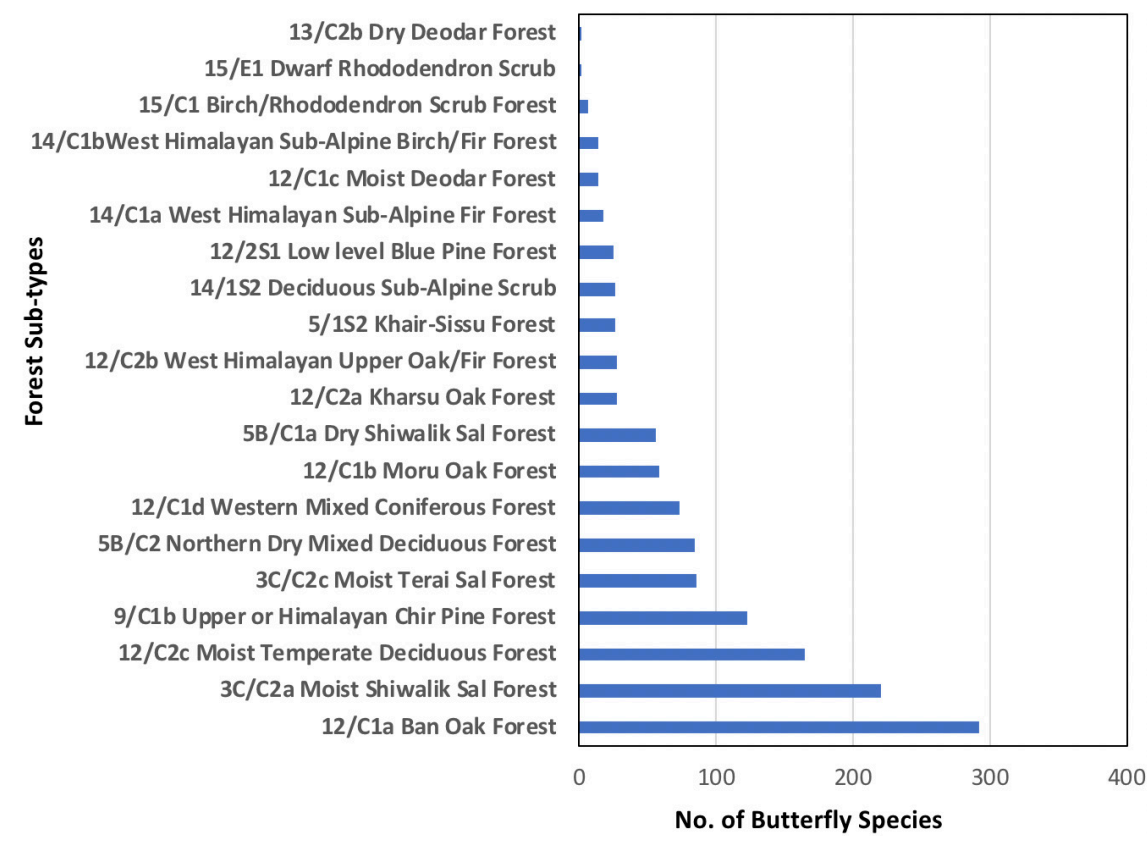

12/2S1 Low level Blue Pine Forest 15/E1 Dwarf Rhododendron Scrub 15/C1 Birch/Rhododendron Scrub Forest 14/C1bWest Himalayan Sub-Alpine Birch/Fir Forest 14/C1a West Himalayan Sub-Alpine Fir Forest 14/1S2 Deciduous Sub-Alpine Scrub

12/C2c Moist Temperate Deciduous Forest 12/C2b West Himalayan Upper Oak/Fir Forest 12/C2a Kharsu Oak Forest

12/C1e Moist Temperate Deciduous Forest

12/C1d Western Mixed Coniferous Forest 12/C1c Moist Deodar Forest 12/C1b Moru Oak Forest 12/C1a Ban Oak Forest 9/C1b Upper or Himalayan Chir Pine Forest 5B/C2 Northern Dry Mixed Deciduous Forest 5B/C1a Dry Shiwalik Sal Forest 5/1S2 Khair-Sissu Forest

3C/C2c Moist Terai Sal Forest 3C/C2a Moist Shiwalik Sal Forest

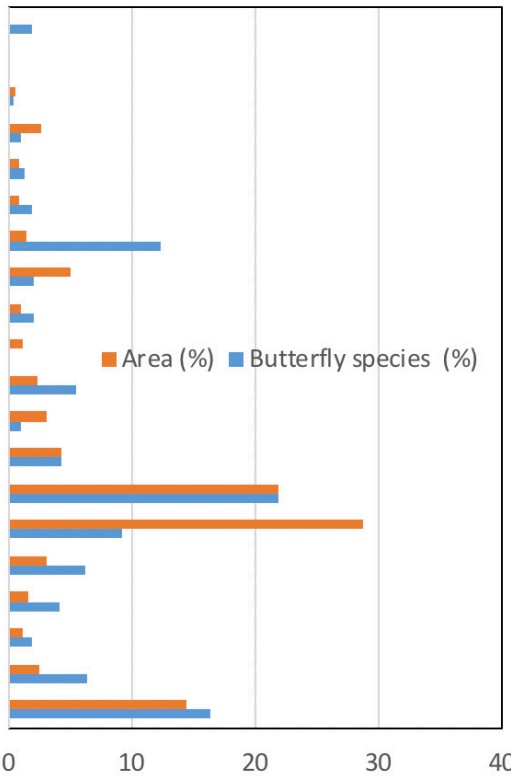

Figure 4. Relative distribution of butterfly species in different forest sub-types in Uttarakhand.
Figure 5. Percentage of butterfly species in each forest sub-type in relation to the proportional area covered by each forest sub-type in Uttarakhand. 
Q1= 1-7 Uncommon (1= rare); 8-21= Fairly Common; 22-69 = Common; 70-1,596 = Very Common Median= 21 (Table 4 and an "Appendix iii" with an account of 370 taxa). Sixty-seven species sampled are listed under various schedules of the Indian Wildlife Protection Act, 1972 (appendix: Schedule I-8 species; Schedule II-51 \& Schedule IV-8). The seasonality of butterflies suggests that most of the species are in flight during 'post-monsoon' and 'pre-monsoon' seasons followed by 'monsoon' season, respectively when more than 270 species are in flight (Figure 3 ) in the state.

The pattern of seasonality in Uttarakhand is very similar to the trend found in western and central Himalaya (Wynter-Blyth 1957) where two peaks are known to occur in a year, the bigger one during the 'post-monsoon' season and a slightly smaller one during the 'pre-monsoon' season.

\section{Preference for Forest Sub-types}

The highest number of species were recorded in 12/ c1a Ban Oak Forest (292 species; Fig.4) followed by 3C/ C2a Moist Shiwalik Sal Forest (220) and 12/C2c Moist Temperate Deciduous Forest (165), respectively which suggests that these forest sub-types hold the major diversity of butterflies found in the state. The number of species sampled were the least in 13/C2b Dry Deodar Forest (14), 15/C1 Birch Rhododendron Scrub (6) and 15/E1 Dwarf Rhododendron Scrub (2), respectively (Figure 4) suggesting them to be poor butterfly habitats, while the other 14 forest sub-types lay between them.

The percentage of butterfly species in each forest sub-type in relation to the proportional area covered by each in the state (Figure 5), suggests that forest subtypes: 9/C1b Upper or Himalayan Chir Pine Forest; 12/ C2b West Himalayan Upper Oak/Fir Forest and 14/C1 B Western Himalayan Sub-alpine Birch/Fir Forest, support a relatively lower number of butterfly species per unit area as compared to the rest of the other forest subtypes (Figure 4). On the other hand forest sub-types: 3C/C2 Moist Shiwalik Sal Forest; 12/C1a Ban Oak Forest; 12/C2C Moist Temperate Deciduous Forest and 12/ C1d Western Mixed Coniferous Forest have a relatively higher density of butterfly species per unit area amongst all the forest sub-types covered (Figure 5). The primary reason for this is that pure conifer forest stands support less diversity of butterflies as compared to the pure broad leaved or mixed conifer-broad leaved forests, as the diversity of nectar and larval food plants available are more diverse in the latter two than in the former.

\section{Hierarchical clustering of forest sub-types}

It was found that 7 forest-types butterfly clusters, 5 independent forest-subtypes and 2 clusters of 2 and 11 forest sub-types, respectively exist in the state (Fig.6). These are

1. $3 \mathrm{C} / \mathrm{C} 2 \mathrm{a}$ Moist Shiwalik Sal Forest.

2. $12 / \mathrm{C} 2 \mathrm{c}$ Moist Temperate Deciduous Forest

3. $12 / \mathrm{C} 1 \mathrm{a}$ Ban Oak Forest.

4. $3 \mathrm{C} / \mathrm{C} 2 \mathrm{c}$ Moist Terai Sal Forest

5. 9/C1b Upper or Himalayan Chir Pine

6. $5 B / C 2$ Northern Dry Mixed Deciduous Forest \& 5B/C1a Dry Shiwalik Sal Forest.

7. 12/C1b Moru Oak; 12/C2b Western Himalayan Upper Oak Forest/Fir; 12/C1d Western Mixed Coniferous; 12/2S1 Low Level Blue Pine; 12/C2a Kharsu Oak Forest; 14/C1a West Himalayan Sub-alpine Fir; 14/C1 Best Himalayan Sub-alpine Birch/Fir/ 14/1S2 Deciduous Subalpine Scrub \& 15/C1 Birch/Rhododendron Scrub.

The dendrogram (Figure 6) suggests that the butterfly community of $3 \mathrm{C} / \mathrm{C} 2 \mathrm{a}$ Moist Shiwalik Sal Forest is totally distinct from that of 12/C2c Moist Temperate Deciduous Forest and 12/C1a Ban Oak forest. While 12/C1a Ban Oak Forest and 12/C2c Moist Temperate Deciduous Forest show greatest similarity. While diversity of $5 B / C 2$ Northern Dry Mixed Deciduous Forest and 5B/C1a Dry Siwalik Sal is different from that of $3 \mathrm{C} / \mathrm{C} 2 \mathrm{c}$ Moist Terai Sal Forest or 3C/C2a Moist Shiwalik Sal Forest. Eleven forest sub-types show another cluster being distinct from other groups (Figure 6). Four forest sub-types that are most important in the state in terms of number of both butterfly species and with distinct dissimilarity of butterflies are 3C/C2a Moist Shiwalik Sal Forest; 12/C2c Moist Temperate Deciduous Forest; 12/C1a Ban Oak Forest and $3 \mathrm{C} / \mathrm{C} 2 \mathrm{c}$ Moist Terai Sal Forest.

\section{Species preference of forest sub-types}

Scatter plot (Figure 7) of individual butterfly species ( $n=370$ ) suggests that only one generalist species (Painted Lady Vanessa cardui) had preference for all 14 forest sub-types. While the number of species showing preference for more than five or more forest sub-types were fewer as compared to species showing preference for less than four forest sub-types (Figure 7 Horizontal bars) in the state. The maximum number of species showed preference for two forest sub-types ( $n=90$ species) followed by preference for only one forest subtype ( $n=60$ species). This suggests that a large number of habitat specialist species exist in the state. 
Butterfly abundance linkages between forest sub-types.

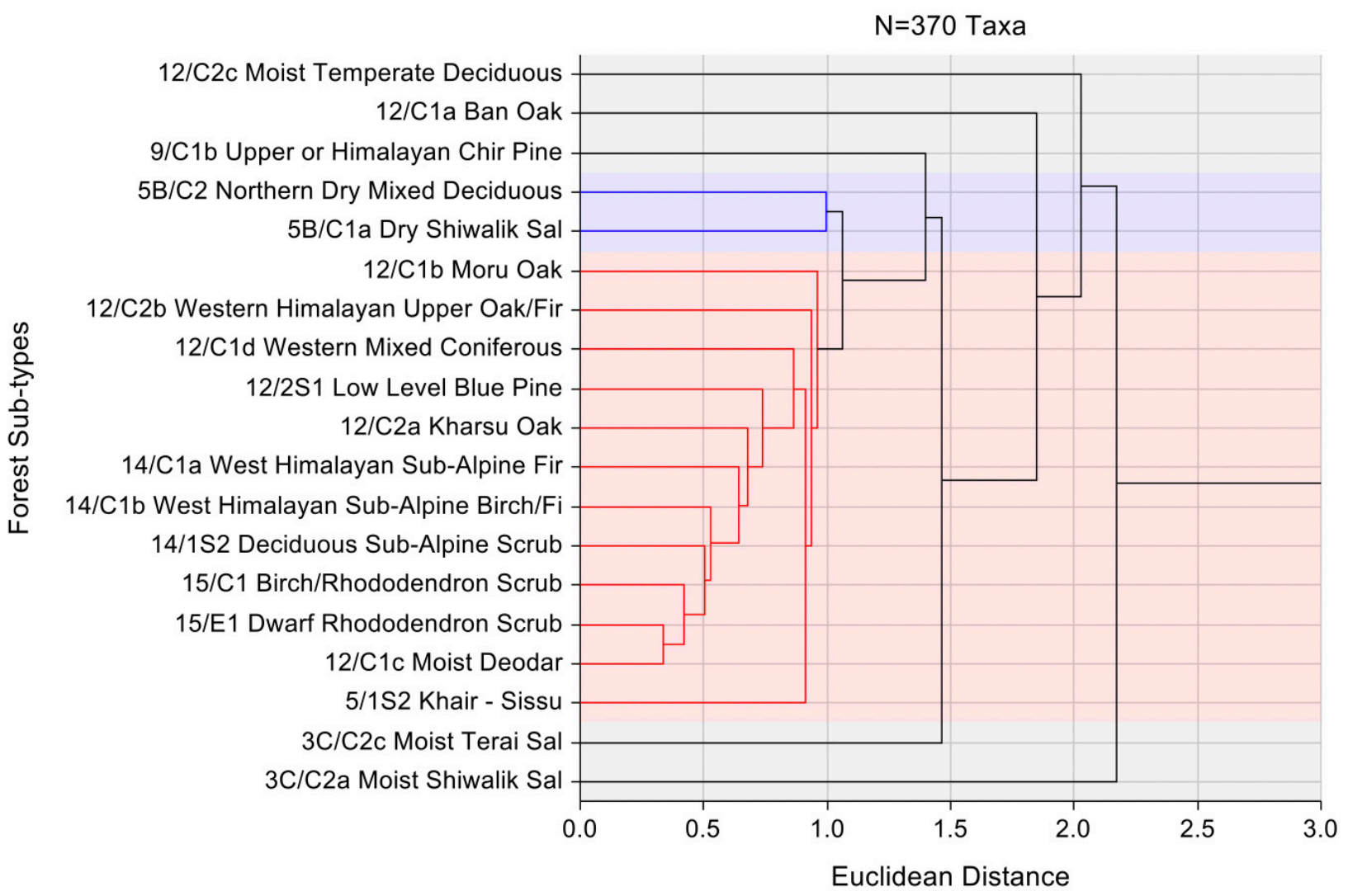

Figure 6. Dendrogram showing hierarchical clustering of forest sub-types in terms of butterfly species in each.

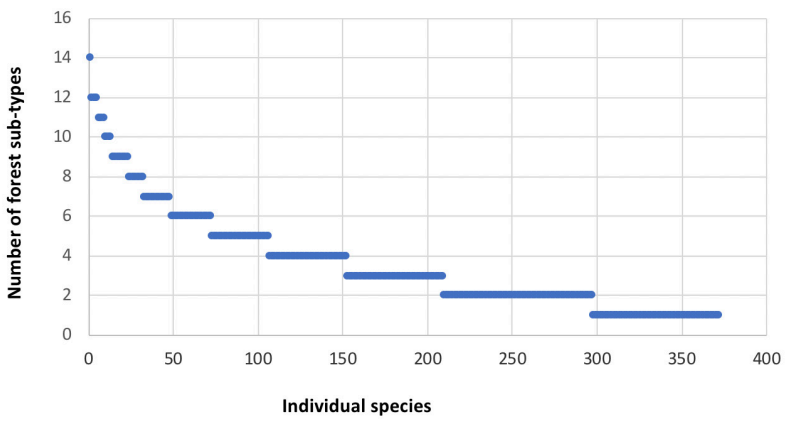

Figure 7. Preference of forest sub-type/s by individual species.

Rarity in butterflies sampled in Uttarakhand: taxa of conservation priority

Out of the 370 taxa sampled in Uttarakhand, 58 were evaluated as rare species of conservation priority /concern based on rarity analysis (Rabinowitz 1981; Rabinowitz et al. 1986) (Appendix IV).

The 58 taxa of conservation concern evaluated based on rarity are scattered all across the state in at least 12 forest sub-types (Figure 8). It was also determined that most of the butterfly taxa of conservation priority occur in 12/C1a Ban Oak Forest followed by $12 / \mathrm{C} 2$ c Moist Temperate Deciduous forest, 3C/C2 Moist Shiwalik Sal Forest and a few taxa in 12/C2b Western Himlayan Upper Oak/Fir Forest; 12/C1d Western Mixed Coniferous Forest, repectively (Figures 8-15).

The present study proved that individual 'forest sub-types'(Champion \& Seth 1968) or a group of 'forest sub-types' having high species richness, unique and rare butterfly taxa can be taken up as units of conservation at the state level in the Himalayan region as representatives of lower groups of animals, i.e., butterflies. Three most important forest sub-types: 12/C1a Ban Oak Forest followed by 12/C2c Moist Temperate Deciduous Forest and 3C/C2 Moist Shiwalik Sal Forest, respectively, hold the maximum number of butterflies, including many rare and protected taxa, in the state amongst the 20 forest sub-types evaluated, thus they form priority over the rest.

The 58 butterfly taxa conservation priority in the state lies both within and outside the PA network, but mainly in forested areas (Figure 16). Concentrations 


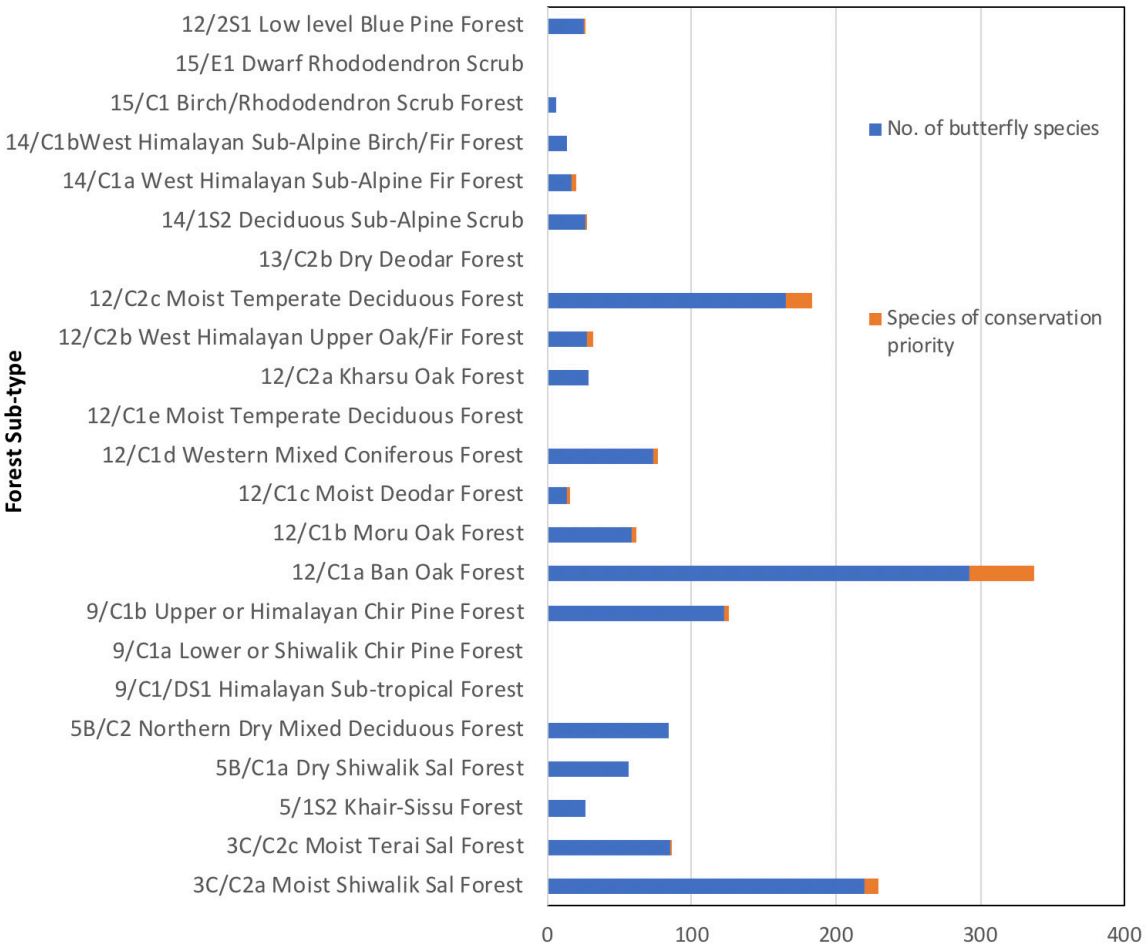

12/2S1 Low level Blue Pine Forest

Dwarf Rhododendron Scrub 1 bWest Himalayan Sub-Alpine Birch/Fir Forest

est Himalayan Sub-Alpine Fir Forest

13/C2 b Dry Deodar Forest

12/C2c Moist Temperate Deciduous Forest

9/C1/DS1 Himalayan Sub-tropical Forest

Dry Mixed Deciduous Forest

5/1S2 Khair-Sissu Forest

3C/C2c Moist Terai Sal Forest

100

200

300

400
Figure 8. Spread of species of conservation priority species ( orange bars) in different forest sub-types in relation to the total number of species sampled in them.

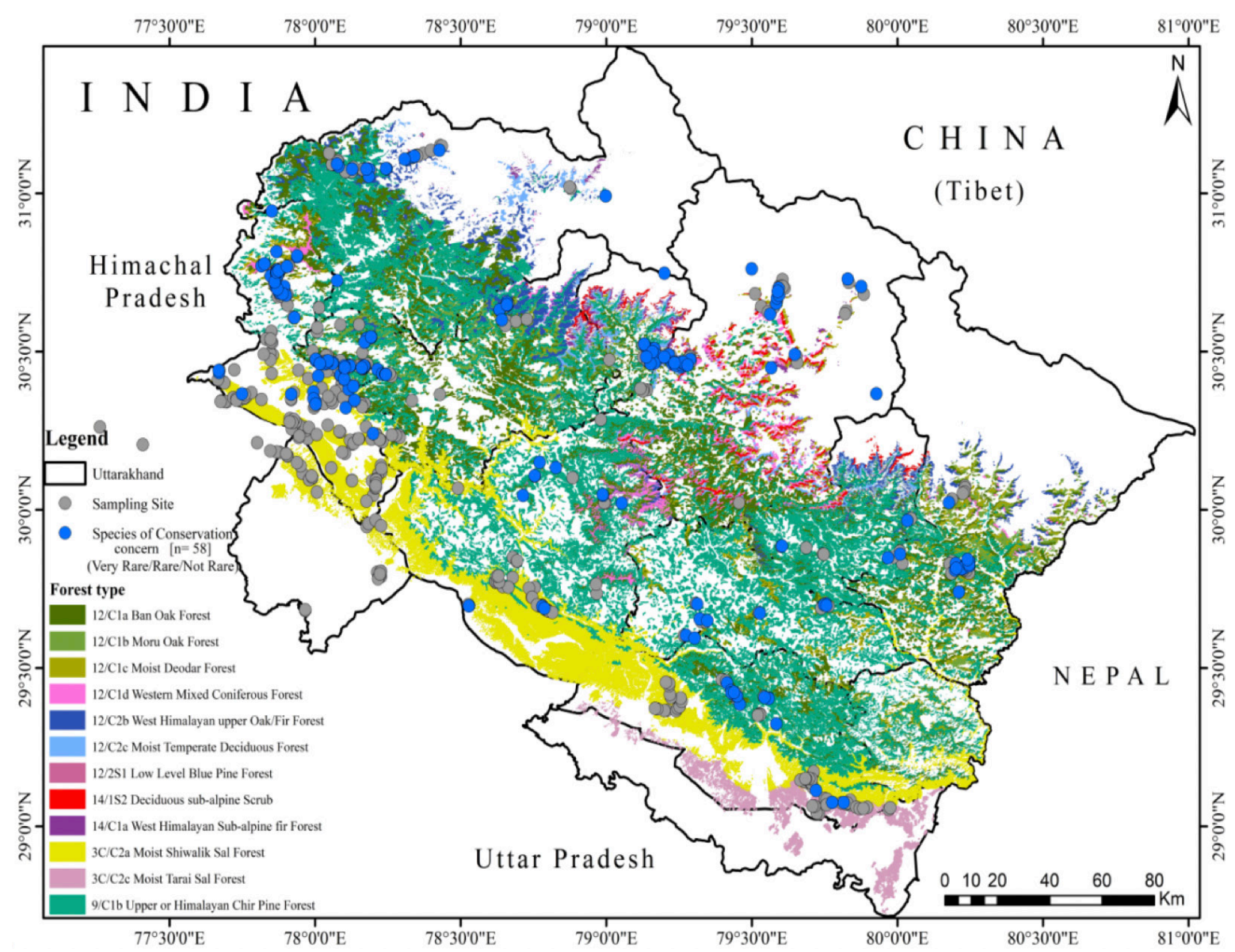

Figure 9. Map depicting the locations recorded for 58 species of conservation priority in 12 different forest sub-types across Uttarakhand. 


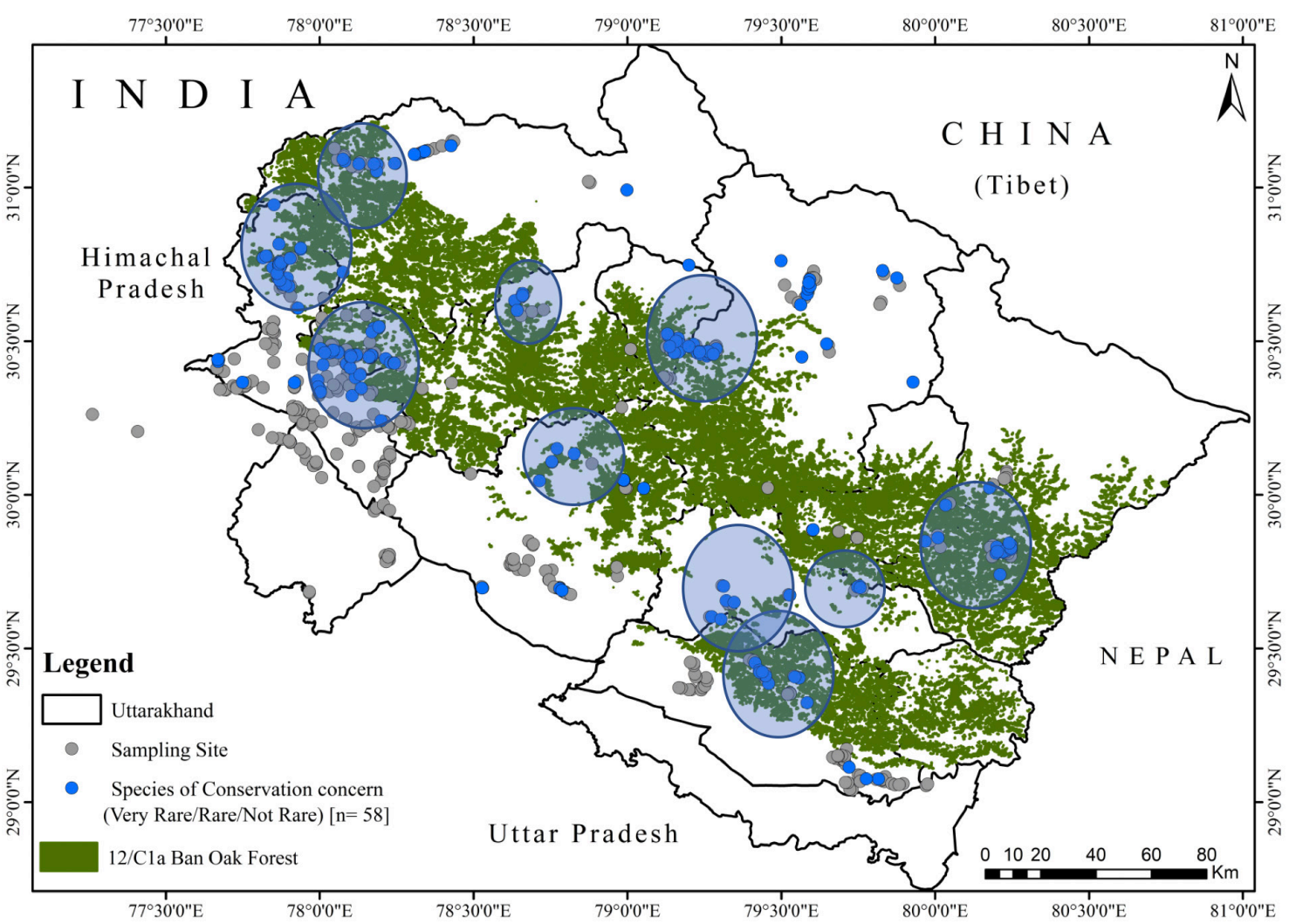

Figure 10. Important clusters of sites holding species of conservation priority in 12/C1a Ban Oak Forest in Uttarakhand.

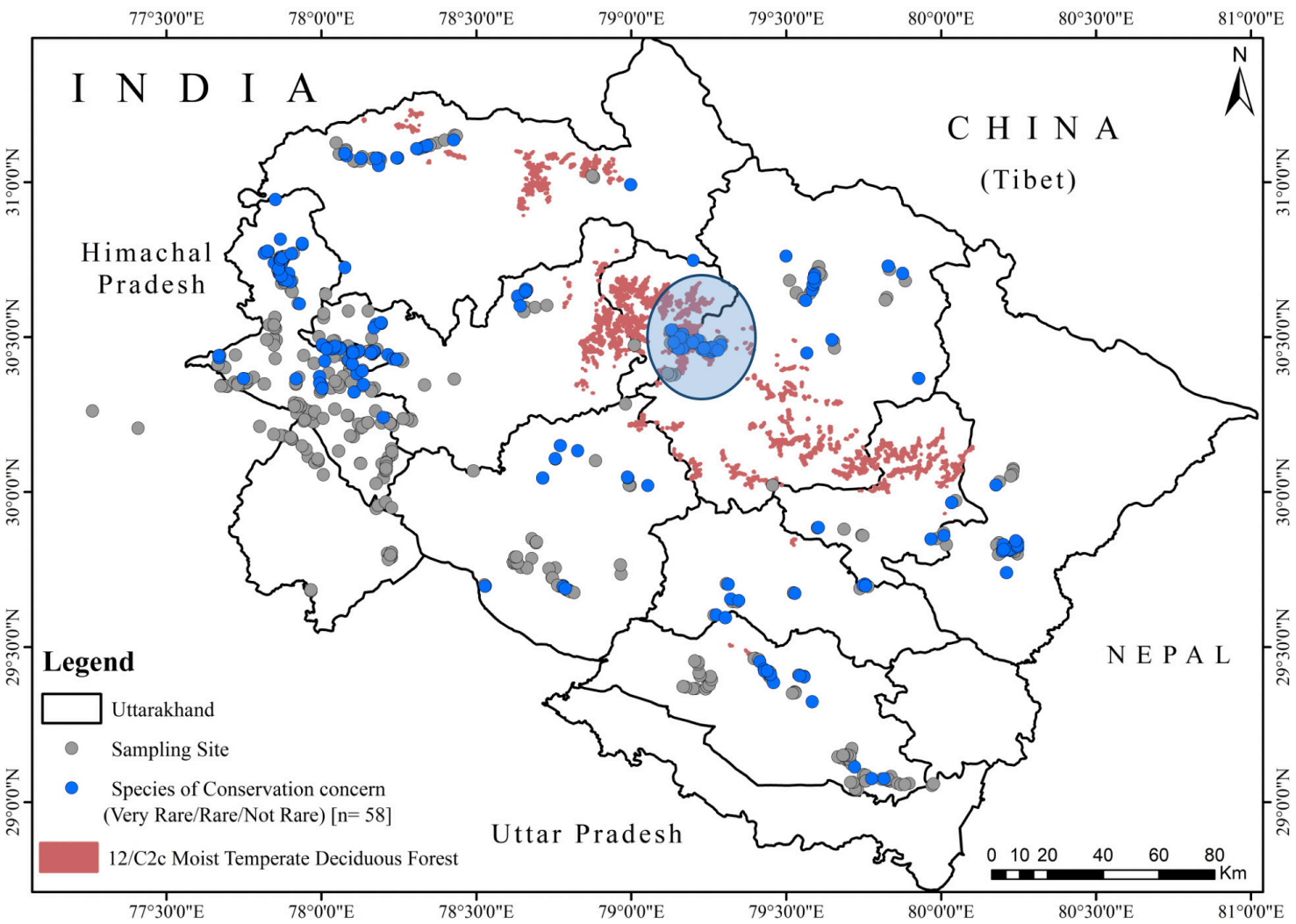

Figure 11. Important clusters of sites holding species of conservation priority in 12/C2c Moist Temperate Deciduous Forest in Uttarakhand. 


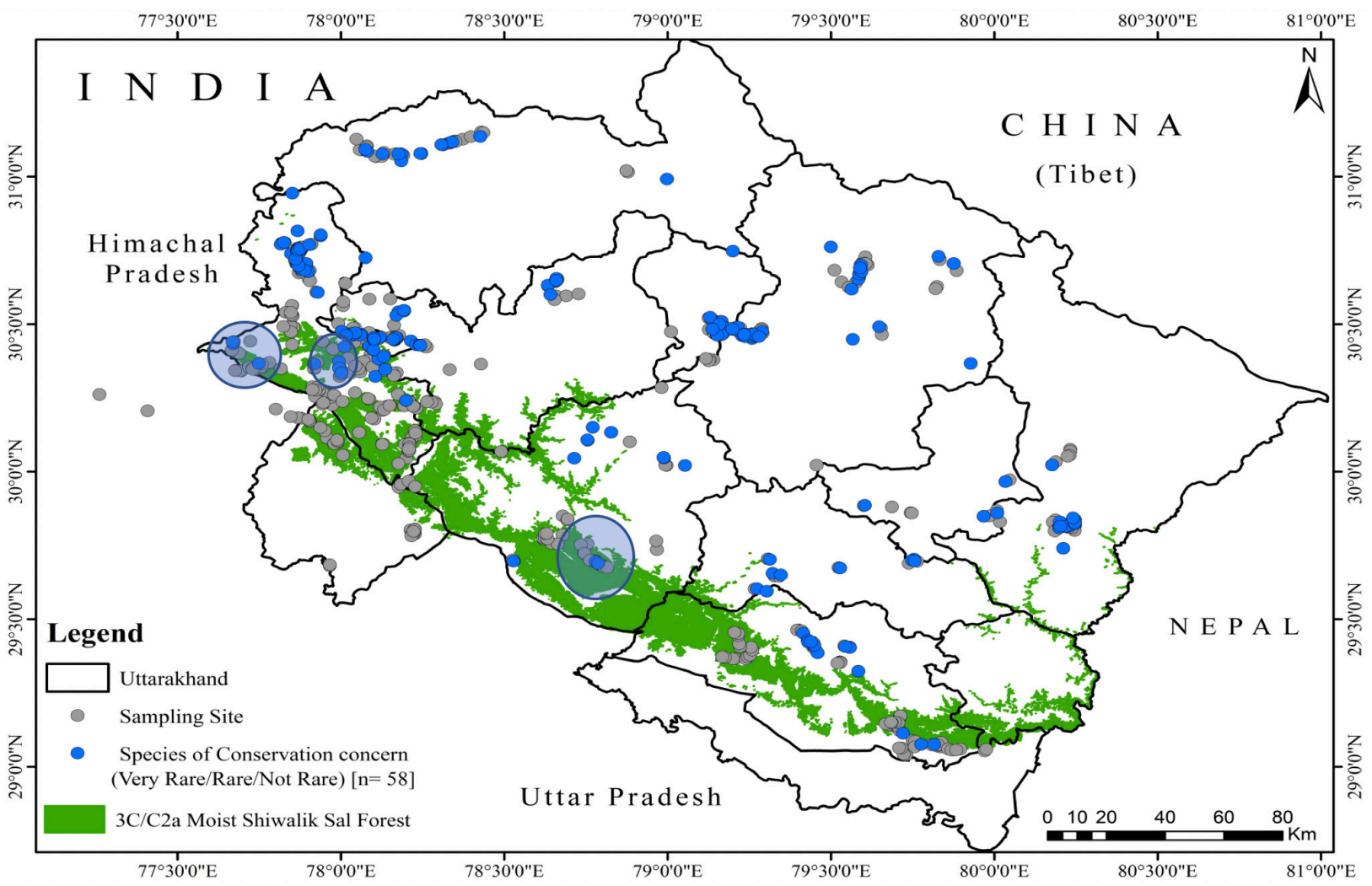

Figure 12. Important clusters of sites holding species of conservation priority in 3C/C2a Moist Shiwalik Sal Forest in Uttarakhand.

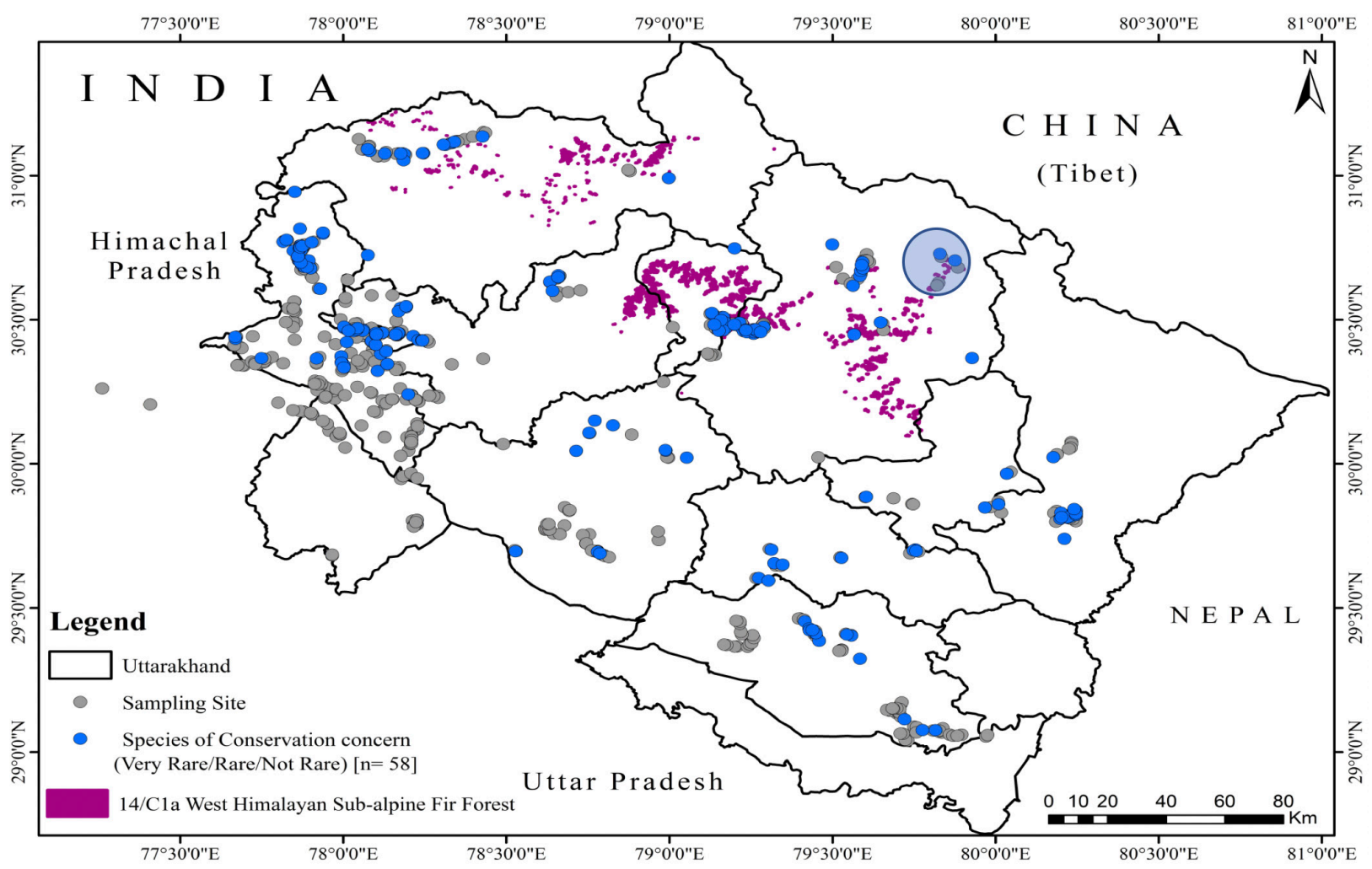

Figure 13. Important cluster of sites holding species of conservation priority in 14/C1a West Himalyan Sub-alpine Fir Forest in Uttarakhand. 


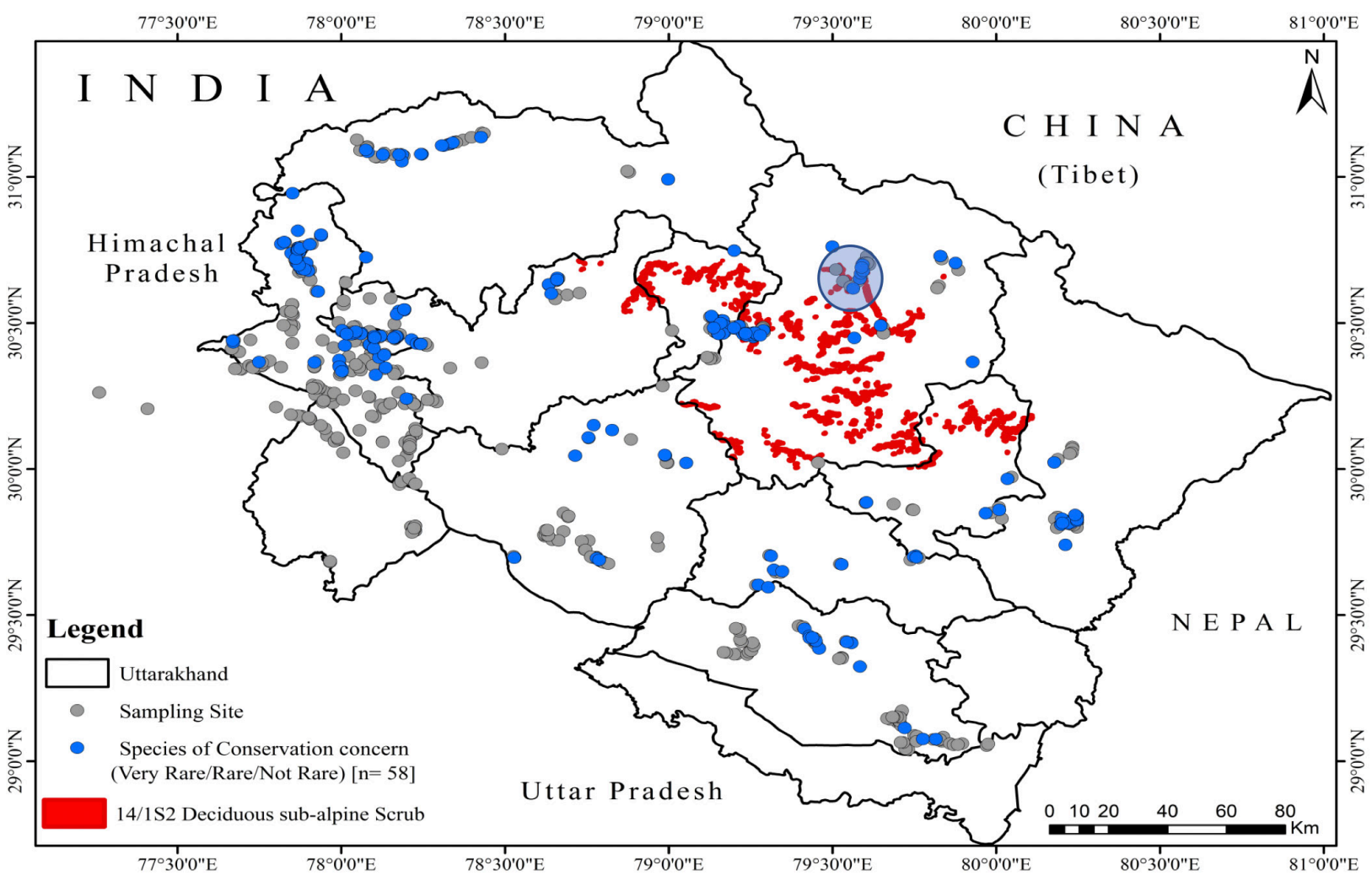

Figure 14. Important cluster of sites holding species of conservation priority in 14/1S2 Deciduous Sub-alpine Scrub in Uttarakhand.

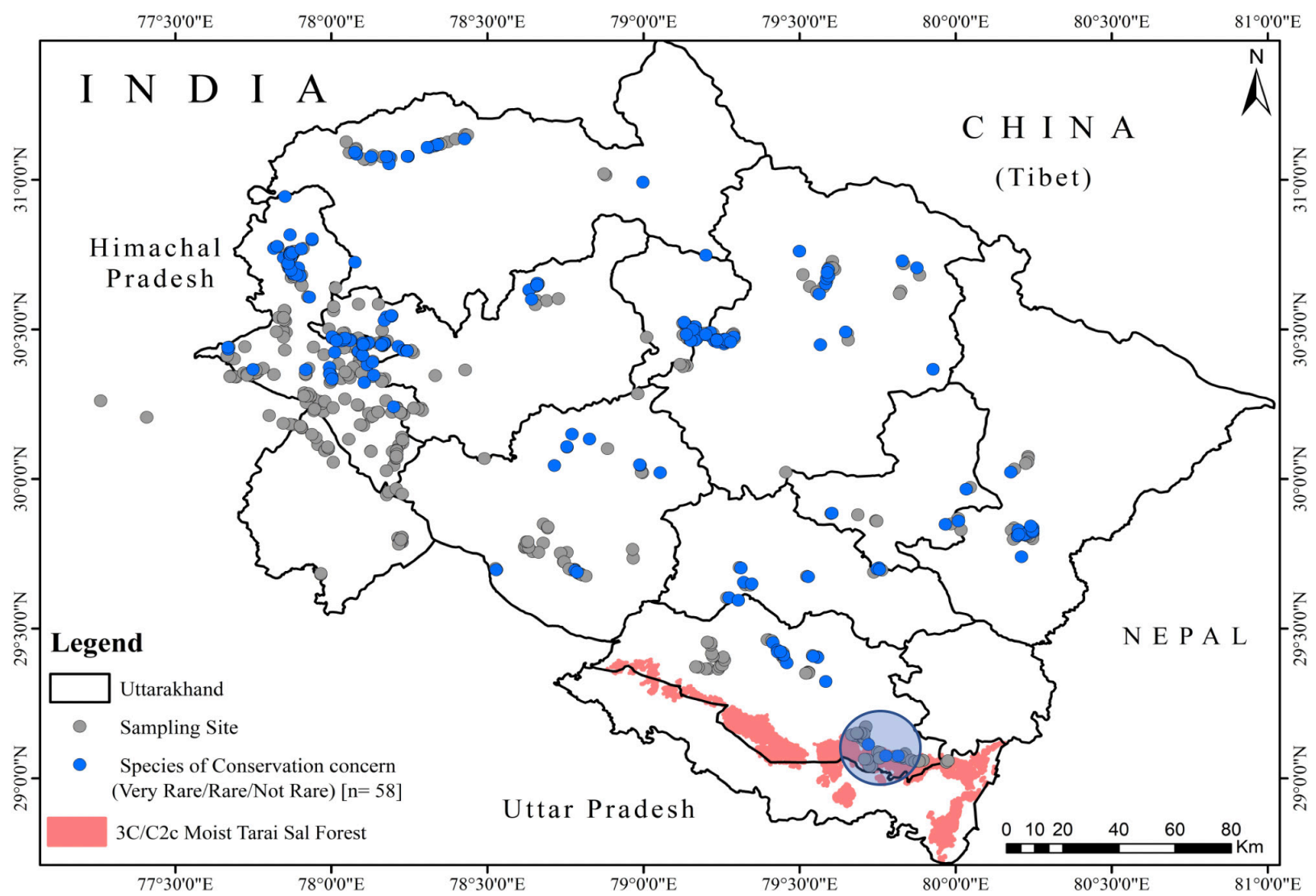

Figure 15. Important clusters of sites holding species of conservation priority in 3C/C2c Moist Terai Sal Forest in Uttarakhand. 


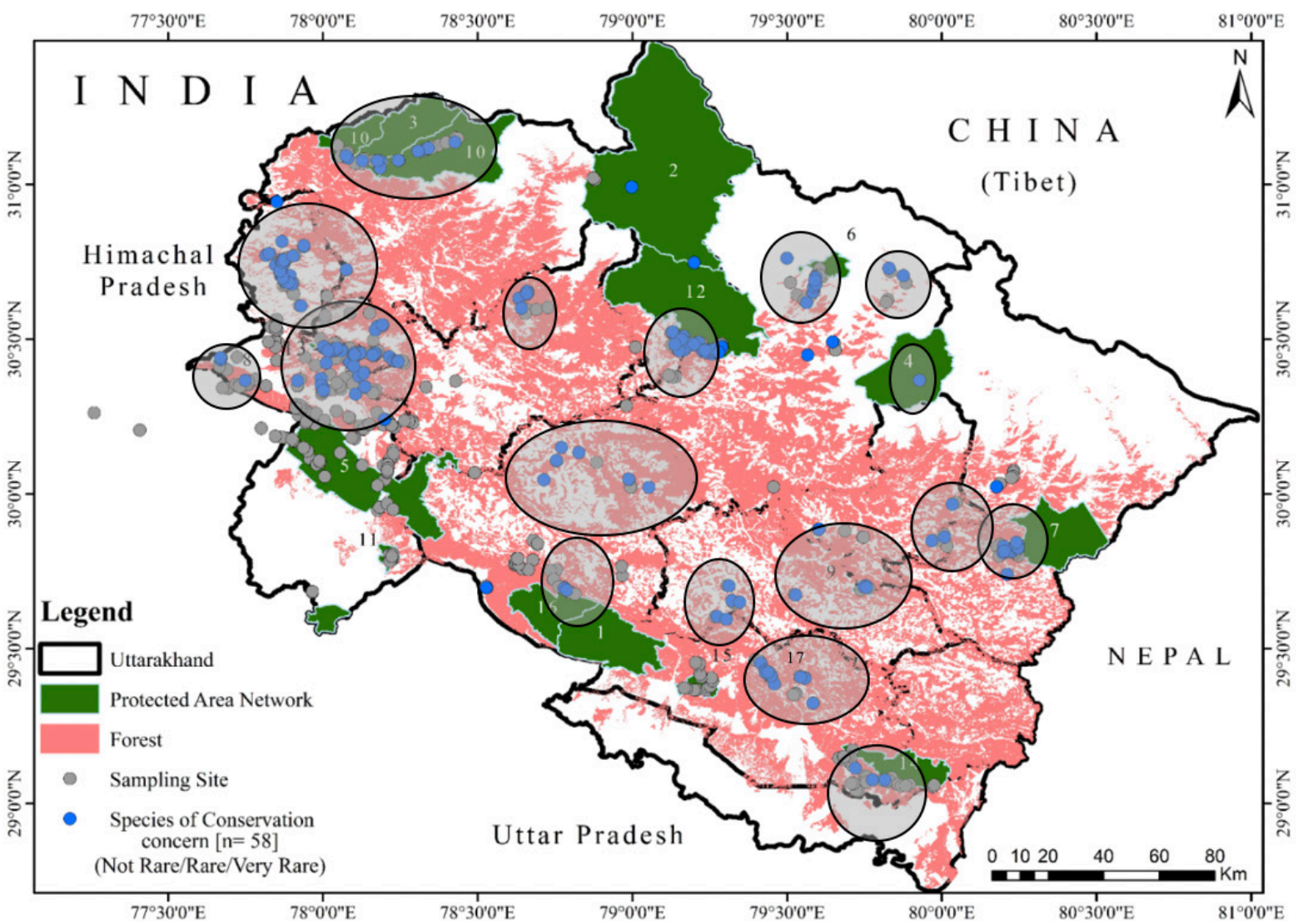

Figure 16. Locations of 58 butterfly species of conservation priority in relation to forest cover and the protected area network (16 no.), of Uttarakhand state along with 17 clusters where these species are concentrated.

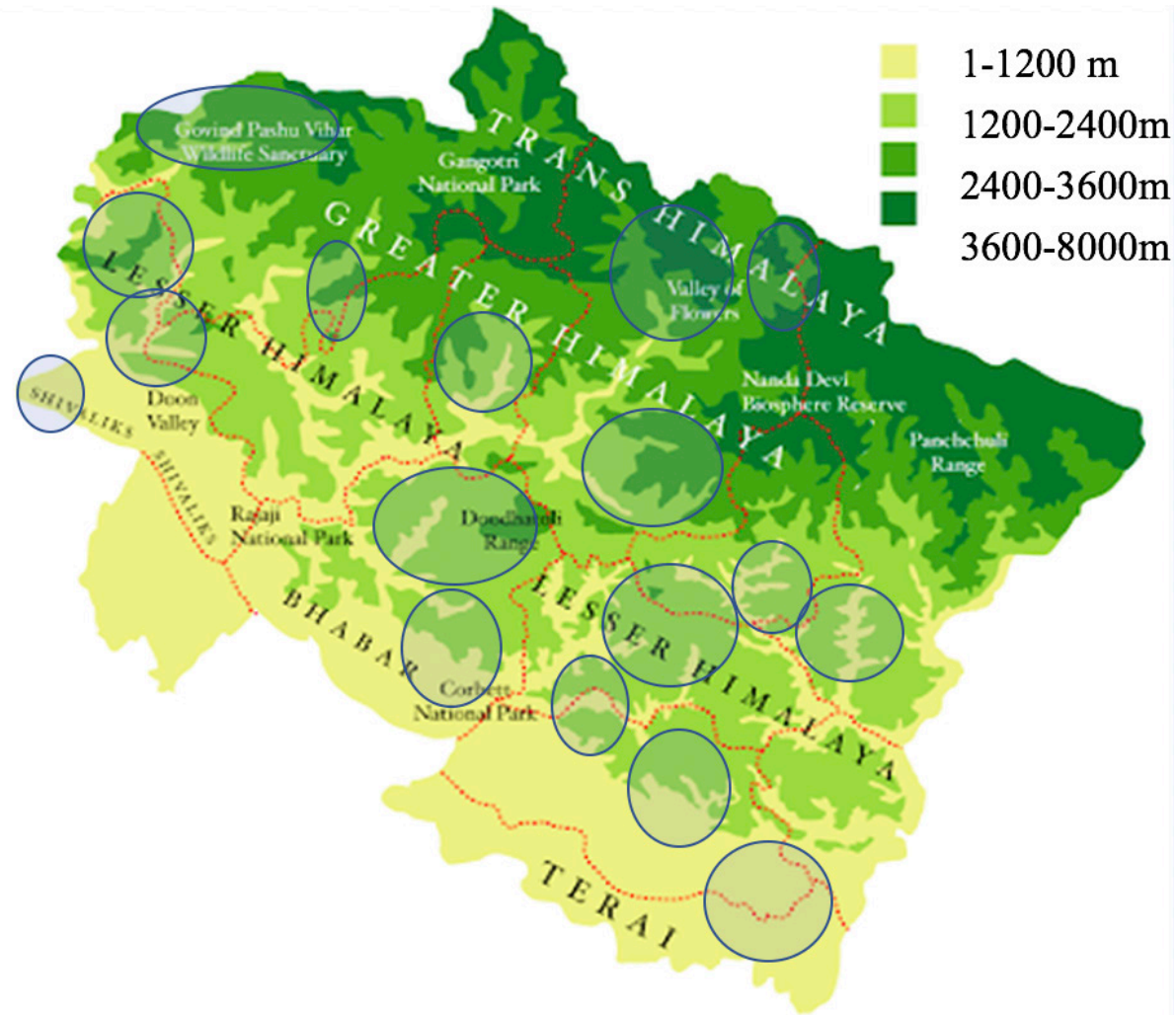

Figure 17. Locations of 17 clusters showing concentration of 58 butterfly species of conservation priority in relation to their altitudinal distribution in the state of Uttarakhand. 


\begin{tabular}{|c|l|}
\hline Sno & Name \\
\hline 1 & Corbett National Park \\
\hline 2 & Gangotri National Park \\
\hline 3 & Govind National Park \\
\hline 4 & Nanda Devi National Park \\
\hline 5 & Rajaji National Park \\
\hline 6 & Valley of Flowers National Park \\
\hline 7 & Askot Wildlife Sanctuary \\
\hline 8 & Asan Conservation Reserve \\
\hline 9 & Binsar Wildlife Sanctuary \\
\hline 10 & Govind Wildlife Sanctuary \\
\hline 11 & Jhilmil Conservation Reserve \\
\hline 12 & Kedarnath Wildlife Sanctuary \\
\hline 13 & Benog/Mussoorie Wildlife Sanctuary \\
\hline 14 & Nandhaur Wildlife Sanctuary \\
\hline 15 & Pawalgarh Conservation Reserve \\
\hline 16 & Sonanadi Wildlife Sanctuary \\
\hline 17 & Naina Devi Bird Conservation Reserve \\
\hline
\end{tabular}

of 58 species of conservation priority are marked in 17 circles (Figure 16) and at least 12 of these occur outside the PA network based on the findings of the present study. Important forest sub-types identified falling in these clusters having species of conservation concern can thus be recommended for conservation or future PAs. Seventeen concentrations/clusters that are located in different physiographic zones represented in the state are, three in Trans Himalaya; three in Greater Himalaya; eight in Lesser Himalaya; one in Shiwalik/Dun; one in Bhabar; and one in Tarai area along an elevation gradient, rather than a few as currently represented in the PA network of the state (Figure 17 \& Appendix V).

Also, new conservation sites can be identified from these 17 clusters/concentrations of rare buttefly taxa especially in the 'Lesser Himalaya' where the number of PAs are almost negligible. This type of approach in identifying areas of conservation priority is more inclusive and suitable at a sub-regional or state level in restoring linkages and corridors in the PA network, rather than solely based on a broader geographic scale, i.e., zoogeographic zones. Many of these sites with high butterfly richenss that lie outside the PAs and close to the villages and towns with suitable logistical support for boarding, lodging and travel can be promoted for suitainable and inclusive butterfly ecotourism activities in the state.

\section{REFERENCES}

Anonymous (2006). The Wildlife (Protection) Act 1972. Natraj Publishers, Dehradun, 235 pp.

Arita, H.T., J.G. Robinson \& K.H. Redford (1990). Rarity in Neotropical forest mammals and its ecological correlates. Conservation Biology 4(2): 181-192.

Baindur, A. (1993). The butterflies of Nanda Devi. In: Scientific and Ecological Expedition Nanda Devi, 2nd May to 22nd July 1993. (Army Corps of Engineers; W.I.I.; Salim Ali Centre for Ornithology \& Natural History, WWF-India, G.B. Pant Institute of Himalayan Environment \& Development, Botanical Survey of India) Army Headquarters, New Delhi, 35-43 pp.

Bhardwaj, M., V.P. Uniyal, A.K. Sanyal \& A.P. Singh (2012). Butterfly communities along an elevation gradient in the Tons valley, Western Himalayas: Implications of rapid assessment of insect conservation. Journal of Asia-Pacific Entomology 15(1): 207-217.

Bhardwaj, M. \& V.P. Uniyal (2013). High-altitude butterfly fauna of Gangotri National Park, Uttarakhand: Patterns in species abundance, composition and similarity,pp38-48. ENVIS Bulletin on Wildlife and Protected Areas- Arthropods and their Conservation in India (Insects \& Spiders), $232 \mathrm{pp}$.

Berg, A. \& M. Tjernberg (1996). Common and rare Swedish vertebrates distribution and habitat preferences. Biodiversity and Conservation 5(1): 101-128.

Bingham, C.T. (1905). Fauna of British India. Butterflies Vol. I. Taylor and Francis, London, $511 \mathrm{pp}$.

Botanical Survey of India (2021). Bibliography and Abstracts of Papers on Flora of Uttar Pradesh and Uttarakhand. ENVIS, Government of India Ministry of Environment, Forest and Climate Change. Botanical Survey of India, Howrah, West Bengal, 616 pp.

Brandis, D. (1906). Indian Trees : An Account of Trees, Shrubs, Woody Climbers, Bamboos, and Palms Indigenous or Commonly Cultivated in the British Indian Empire. Archibald Constable and Co., Ltd. London, $767 \mathrm{pp}$.

Brown, J.H. (1995). Macroecology. University of Chicago Press, Chicago, IL, 284 pp.

Brown, K.S. (1982). Paleoecology and regional patterns of evolution in neotropical forest butterflies, pp. 255-308. In: Prance, G.T. (ed). Biological Diversification in the Tropics. Columbia University Press, New York, 714 pp.

Champion, H.G. \& S.K. Seth (1968). A Revised Survey of The Forest Type of India. Govt. of India Press. New Delhi, 404 pp.

D’abrera, B. (1982). Butterflies of the Oriental Region - Part I. Papilionidae, Pieridae \& Danaidae. Hill House, Victoria, Australia, 244 pp.

D'abrera, B. (1985). Butterflies of the Oriental Region - Part II. Nymphalidae, Satyridae \& Amathusiidae. Hill House, Victoria, Australia, $534 \mathrm{pp}$.

D'abrera, B. (1986). Butterflies of the Oriental Region - Part III. Lycaenidae \& Riodinidae. Hill House, Victoria, Australia, 672 pp.

Daniels, R.J.R., M. Hegde, N.V. Joshi \& M. Gadgil (1991). Assigning conservation value: a case study from India. Conservation Biology 5(4): 464-475.

Doherty, W. (1886). A list of butterflies in Kumaun. Journal of the Asiatic Society of Bengal 55(2): 103-140.

Ehrlich, P.R. \& P.H. Raven (1964). Butterflies and plants: a study in coevolution. Evolution 18: 586-608.

Evans, W.H. (1932). The Identification of Indian Butterflies. 2nd Edition. Bombay Natural History Society, Bombay, x+454 pp+32 pl.

Forest Survey of India (2011). Atlas-Forest Types of India. Forest Survey of India, Ministry of Environment and Forests, Govt. of India, Dehradun, 210 pp.

Gaston, K.J. (1994). Rarity. Chapman and Hall, London, 201 pp.

Gaston, K.J. \& T.M. Blackburn (1995). Rarity and body size: some cautionary remarks. Conservation Biology 9(1): 210-213.

Gilbert, L.E. \& M.C. Singer (1975). Butterfly Ecology. Annual Review of Ecology and Systematics 6(1): 365-397.

Gilbert, L.E. \& J.T. Smiley (1978). Determinants of local diversity in 
phytophagous insects: host specialists in tropical environments, pp. 89-104. In: Mound, L.A. \& N. Waloff (eds.). Diversity of Insect Faunas. Blackwell Scientific, 204 pp.

Gilbert, L.E. (1980). Food web organization and the conservation of neotropical diversity, pp. 11-34. In: Soule, M.E. \& B.A. Wilcox (eds.). Conservation Biology: An Evolutionary-Ecological Perspective. Sinauer Associates, Sunderland, Massachusetts, USA, 395 pp.

Gilbert, L.E. (1984). The biology of butterfly communities, pp 41-54. In: Vane-Wright, R.I. \& P.R. Ackery (eds.). The Biology of Butterflies. Princeton University Press, Princeton, New Jersey, USA, 429 pp.

Gasse, P.V. (2017). Annotated checklist of Butterflies of the IndoBurmese region. http://flutters.org/home/docs/Butterflies_of_ India_Paul Van Gasse.pdf

Hannyngton, F. (1910-11). The butterflies of Kumaon. Parts I \& Part II. Journal of the Bombay Natural History Society 20 (1): 130-142; (2): 361-372; (3): 871-872.

Haribal, M. (1992). Butterflies of Sikkim Himalaya and their Natura History. Sikkim Nature Conservation Foundation, Gangtok, Sikkim, India, $217 \mathrm{pp}$.

Khanduri, K., A. Singh, D. Singh, Kursotam \& P. Garg (2013) Uttarakhand Himalayas: Hydropower Developments and its Impact on Environmental System. Journal of Environment. Volume 02. https://www.researchgate.net/publication/264673061.

Kehimkar, I. (2008). The Book of Indian Butterflies. Bombay Natura History Society, Oxford University, Delhi Press, 497 pp.

Kehimkar, I. (2016). Butterflies of India. Bombay Natural History Society, Mumbai, $505 \mathrm{pp}$.

Kremen, C. (1992). Assessing the Indicator Properties of Species Assemblages for Natural Areas Monitoring. Ecological Applications 2(2): 203-217.

Kremen, C., R.K. Colwell, T.L. Erwin, D.D. Murphy, R.F. Noss \& M.A. Sanjayan (1993). Terrestrial arthropod assemblages: Their use in conservation planning. Conservation Biology 7(4): 796-808.

Lomov, B., D.A. Keith, D.R. Britton \& D.F. Hochuli (2006). Are butterflies and moths useful indicators for restoration monitoring? A pilot study in Sydney's Cumberland Plain Woodland 7(3): 204-210. https://doi. org/10.1111/j.1442-8903.2006.00310.x

Mackinnon, P.W. \& L. DeNicéville (1899). List of butterflies of Mussoorie in the Western Himalayas and neighbouring region Journal Bombay Natural History Society 11(1): 205-221; (2): 368389, 585-605.

Moore, F. (1890-1897). Lepidoptera indica. Parts I-VII. Lovell Reeve Co.Ltd. London.

Murphy, D.D. \& B.A. Wilcox (1986). Butterfly diversity in natura habitat fragments: a test of the validity of vertebrate-based management, pp. 287-292 . In: Verner, J., M.L. Morrison \& C.J. Ralph (eds.). Wildlife 2000, Modeling Habitat Relationships of Terrestrial Vertebrates. University of Wisconsin Press, Madison, Wisconsin, USA, $699 \mathrm{pp}$

Murphy, D.D., K.E. Freas \& S.B. Weiss (1990). An environmentmetapopulation approach to population viability analysis for a threatened invertebrate. Conservation Biology 4(1): 41-51.

Nayar, M.P. \& A.R.K. Sastry (1987, 1988, 1990). Red Data Book of Indian Plants Vols. I, II, III. Botanical Survey of India, Calcutta.

New, T.R. (1991). Butterfly Conservation. Oxford University Press, 224 $\mathrm{pp}$.

New, T.R., R.M. Pyle, J. A. Thomas, C.D. Thomas \& P.C. Hammond (1995). Butterfly conservation management. Annual Review of Entomology 40 (1): 57-83.

Ollenbach, O.C. (1930). Butterfly collection grounds at Mussoorie Journal of the Bombay Natural History Society 34(3): 836-840.

Pearman, P.B., M. Guerreiro, T.D. Sisk \& D. Murphy (1995). Correlation patterns among groups proposed as biological indicators : what do they indicate. Bulletin of the Ecological Society of America 76: 375.

Pimm, S.L., L.H. Jones \& J. Diamond (1988). On the risk of extintion. American Naturalist 132(6): 757-785.I

Pollard, E. (1977). A method for assessing changes in the abundance of butterflies. Biological Conservation 12(2): 115-124.

Pollard, E. \& T.J. Yates (1993). Monitoring Butterflies for Ecology and
Conservation. Chapman and Hall, London, $287 \mathrm{pp}$

Pyle, R.M. (1980). Butterfly eco-geography and biological conservation in Washington. Atala 8(1): 1-26.

Primack, R. (1993). Essentials of Conservation Biology. Sinauer Associates, Sunderland, MA, $585 \mathrm{pp}$.

Rabinowitz, D.S., S. Cairns \& T. Dillon (1986). Seven forms of rarity and their frequency in flora of British Isles, pp. 182-204. In: Soule, M.E.(ed.). Conservation Biology: the Science of scarcity and Diversity. Sinuer, Sunderland, M.A, 584 pp.

Rabinowitz, D.S. (1981). Seven forms of rarity, pp. 205-217. In: Synge, H. (ed.). The Biological Aspects of Rare Plant Conservation. Wiley, Chichester, U.K.,558 pp.

Rai, I.D., G. Singh \& G.S. Rawat (2017). Plants of Kedarnath Wildlife Sanctuary, Western Himalaya: A Field Guide. Bishen Singh Mahendra Pal Singh, Dehadun, 393 pp.

Rodgers, W.A. \& H.S Panwar (1988). Planning a Wildlife Protected Area Network in India. 2 vol. Project FO: IND/82/003, FAO, Dehradun 339, $267 \mathrm{pp}$.

Rosenberg, D.M., H.V. Danks \& D.M. Lehmkuhl(1986). Importance of insects in environmental impact assessment. Environment impact assessment. Environment Management 10(6): 773-783.

Samways, M.J. (1994). Individual insect species and their conservation, pp. 169-193. In: Insect Conservation Biology. Chapman and Hall, London, $450 \mathrm{pp}$.

Shull, E.M. (1958). My highest catch of butterfly species in a single day (4th June, 1957) Mussoorie, India. Journal of the Lepidopterists' Society 11(4-5): 167-168.

Shull, E.M. (1962). Over one hundred butterfly species caught in a single day (3rd June, 1961) at Mussoorie, India. Journal of the Lepidopterists' Society 16: 143-145.

Singh, A.P. (2017). Butterflies associated with major forest types in Arunachal Pradesh (Eastern Himalaya), India: Implications for ecotourism and in conservation planning. Journal of Threatened Taxa 9(4): 10047-10075. https://doi.org/10.11609/jott.2765.9.4.1004710075

Singh, A.P. \& R.S. Bhandari (2003). Butterfly diversity in tropical moist deciduous sal (Shorea robusta) forests of Dehradun valley: the lower western Himalayas. Indian Forester 129(10): 1257-1269.

Singh, A.P. \& R.S. Bhandari (2006). New Additions to the Butterflies of Dehradun valley, the lower Western Himalayas. Indian Forester 132(6): 767-769.

Singh, A.P. \& S. Sondhi (2016). Butterflies of Garhwal, Uttarakhand, western Himalaya, India. Journal of Threatened Taxa 8(4): 86668697. https://doi.org/10.11609/jott.2254.8.4.8666-8697

Singh, A.P. (2016). Recent records of the Pale Jezebel Delias sanaca sanaca (Moore, 1857) (Lepidoptera: Pieridae) from Mussoorie hills, western Himalaya, India. Journal of Threatened Taxa 8(12): 94739478. https://doi.org/10.11609/jott.2834.8.12.9473-9478

Singh, A.P. \& S. Seal (2019). Occurrence of Dark Sapphire Heliophorus indicus Fruhstorfer, 1908 (Lepidoptera: Lycaenidae) in Garhwal Himalaya, Uttarakhand, India. Bugs R All \#175, In: Zoo's Print 34 (7): 33-34.

Singh, A.P. \& T. Singh (2019). Recent records of the rare Mountain Tortoiseshell Aglais rizana (Moore, 1872) (Lepidoptera: Nymphalidae) in the upper Garhwal, western Himalaya, India, after 100 years. Journal of Threatened Taxa 11(15): 15068-15071. https://doi.org/10.11609/jott.5276.11.15.15068-15071

Si gh, A.P. \& T. Singh (2020). Occurrence and association of the Scarce Lilacfork Lethe dura gammiei (Moore, [1892]) (Lepidoptera: Nymphalidae: Satyrinae) with Woolly-leaved Oak Quercus lanata Smith, 1819 (Fabaceae) forest in the Kumaon region of the Indian Himalaya. Journal of Threatened Taxa 12(3): 15387-15390. https:// doi.org/10.11609/jot.5467.12.3.15387-15390

Singh, A.P. \& T. Singh (2021). Habitat association and hybridization in woodbrowns (Lethe nicetas, L. sidonis \& L. dakwania) (Lepidoptera: Nymphalidae: Satyrinae) in Kedarnath Musk Deer Reserve, western Himalaya. Journal of Threatened Taxa 13(3): 1804518049. https://doi.org/10.11609/jott.6517.13.3.18045-18049

Singh, A.P. \& T. Singh (2021). First record of White-ringed 
Meadowbrown, Hyponephele davendra davendra (Moore, 1865) (Lepidoptera: Nymphalidae) from inner valleys of Garhwal, Uttarakhand, India. Journal of Bombay Natural History Society 118(2): 1-5. https://doi.org/10.17087/jbnhs/2021/v118/152490

Singh, A.P. \& T. Singh (2022). Occurrence of Dubious Five-Ring, Ypthima parasakra Eliot in Garhwal Himalaya. Indian Journal of Entomology 84(1): 1-3.

Smetacek, P. (2002). The genus Pontia Fabricius (Lepidoptera: Pieridae) in the Kumaon Himalaya. Journal of the Bombay Natural History Society 99(2): 224-231.

Smetacek, P. (2004). Descriptions of new Lepidoptera from the Kumaon Himalaya. Journal of the Bombay Natural History Society 101(2): 269-276.

Smetacek, P. (2011). Four new Lycaenid records from the Kumaon Himalaya. Journal of Threatened Taxa 3(2): 1555-1558. https://doi. org/10.11609/JoTT.o2224.1555-8

Smetacek, P. (2012). A new sub-species of Mycalesis suaveolens Wood-Mason \& de Niceville 1883 from the western Himalaya, India (Lepidoptera, Nymphalidae, Satyrinae). Nachrichten Entomolgischen Vereins Apollo 32: 105-108.

Smetacek, P. (2012). Butterflies (Lepidoptera: Papilionoidea and Hesperoidea) and other protected fauna of Jones Estate, a dying watershed in the Kumaon Himalaya, Uttarakhand, India. Journal of Threatened Taxa 4(9): 2857-2874. https://doi.org/10.11609/JoTT. o3020.2857-74

Smith, C. (1989). Butterflies of Nepal (Central Himalaya). Tecpress Service L.P., Bangkok, $352 \mathrm{pp}$

Smith, C. (2006). Illustrated Checklist of Nepal Butterflies. Craftman Press, Bangkok, $129 \mathrm{pp}$.

Sondhi, S. (2017). First records of butterflies Anthene emolus emolus (Godart, [1924]) (Lepidoptera: Lycaenidae: Polyommatinae) and Gandaca harina assamica Moore, [1906] (Lepidoptera: Pieridae: Coliadinae) from Kumaon, Uttarakhand, India. Journal of Threatened Taxa 9(6): 10355-10357. https://doi.org/10.11609/ jott.3233.9.6.10355-10357
Sondhi, S. \& K. Kunte (2018). Butterflies of Uttarakhand- A Field Guide. Bishen Singh Mahendra Pal Singh (Dehradun), Titli Trust (Dehradun) National Centre for Biological Sciences (Bengaluru).

Swinhoe, C. (1905-1910). Lepidoptera Indica.Part VII. RhopaloceraPapilionidae \& Lycaenidae. Lovell, Reeve \& Co. Ltd, London, 286 pp +pls.551-639.

Swinhoe, C. (1910-1911). Lepidoptera Indica. Part VIII. Rhopalocera Lycaenidae. Lovell, Reeve \& Co. Ltd., London, 293 pp + pls. 640-705.

Swinhoe, C. (1911-1912). Lepidoptera Indica Part IX. RhopaloceraLycaenidae \& Hesperiidae. Lovell, Reeve \& Co. Ltd., London, 278 pp +pls. 706-756.

Swinhoe, C. (1912-1913). Lepidoptera Indica. Part X. Rhopalocera Hesperiidae. Lovell, Reeve \& Co. Ltd., London, 364 pp + pls. 757-835.

Talbot, G. (1939). The Fauna of British India including Ceylon and Burma. Butterflies. 2nd edition. Vol. I . Taylor \& Francis, London, 600 pp.

Talbot, G. (1947). The Fauna of British India including Ceylon and Burma. Butterflies. 2nd edition. Vol. II. Taylor \& Francis, London, 506 pp.

Thomas, J.A. (1983). A quick method for estimating butterfly numbers during surveys. Biological Conservation 27(3): 195-211.

Thomas, C.D. \& H.C. Mallorie (1985). Rarity, species richness and conservation: butterflies of the Atlas mountains in Morocco. Biological Conservation 33(2): 95-117.

Vasudevan, K. \& S. Sondhi (2010). Amphibians and Reptiles of Uttarakhand, India. Wildlife Institute of India, $53 \mathrm{pp}$.

Verma, A. \& M.K. Arya (2018). A preliminary study on the status and distribution of Butterfly Fauna in and around the valley of Reetha Sahib, Champawat, Kumaun Himalaya, India. Biological Forum- An International Journal 10(1): 43-51.

Wells, S.M., M.R. Pyle \& M. Collins (1983).The IUCN invertebrate Red Data Book. IUCN, Switzerland, 623 pp.

Wynter-Blyth, M.A. (1957). Butterflies of the Indian Region. Bombay Natural History Society, Bombay, $x x+523$ pp+72 pls. 
Appendix I. List of protected areas in Uttarakhand state, India

\begin{tabular}{|c|c|c|}
\hline & Name & Area $\left(\mathrm{km}^{2}\right)$ \\
\hline 1 & Corbett National Park & 520.82 \\
\hline 2 & Gangotri National Park & 2390 \\
\hline 3 & Govind National Park & 558.88 \\
\hline 4 & Nanda Devi National Park & 624.6 \\
\hline 5 & Rajaji National Park & 819.54 \\
\hline 6 & Valley of Flowers National Park & 87.50 \\
\hline 7 & Askot Wildlife Sanctuary & 600 \\
\hline 8 & Asan Conservation Reserve & 4.44 \\
\hline 9 & Binsar Wildlife Sanctuary & 45.59 \\
\hline 10 & Govind Wildlife Sanctuary & 481.05 \\
\hline 11 & Jhilmil Conservation Reserve & 37.84 \\
\hline 12 & Kedarnath Wildlife Sanctuary & 975.20 \\
\hline 13 & Benog/Mussoorie Wildlife Sanctuary & 10.82 \\
\hline 14 & Nandhaur Wildlife Sanctuary & 269.96 \\
\hline 15 & Pawalgarh Conservation Reserve & 58.25 \\
\hline 16 & Sonanadi Wildlife Sanctuary & 301.18 \\
\hline 17 & Naina Devi Bird Conservation Reserve & 111.90 \\
\hline
\end{tabular}

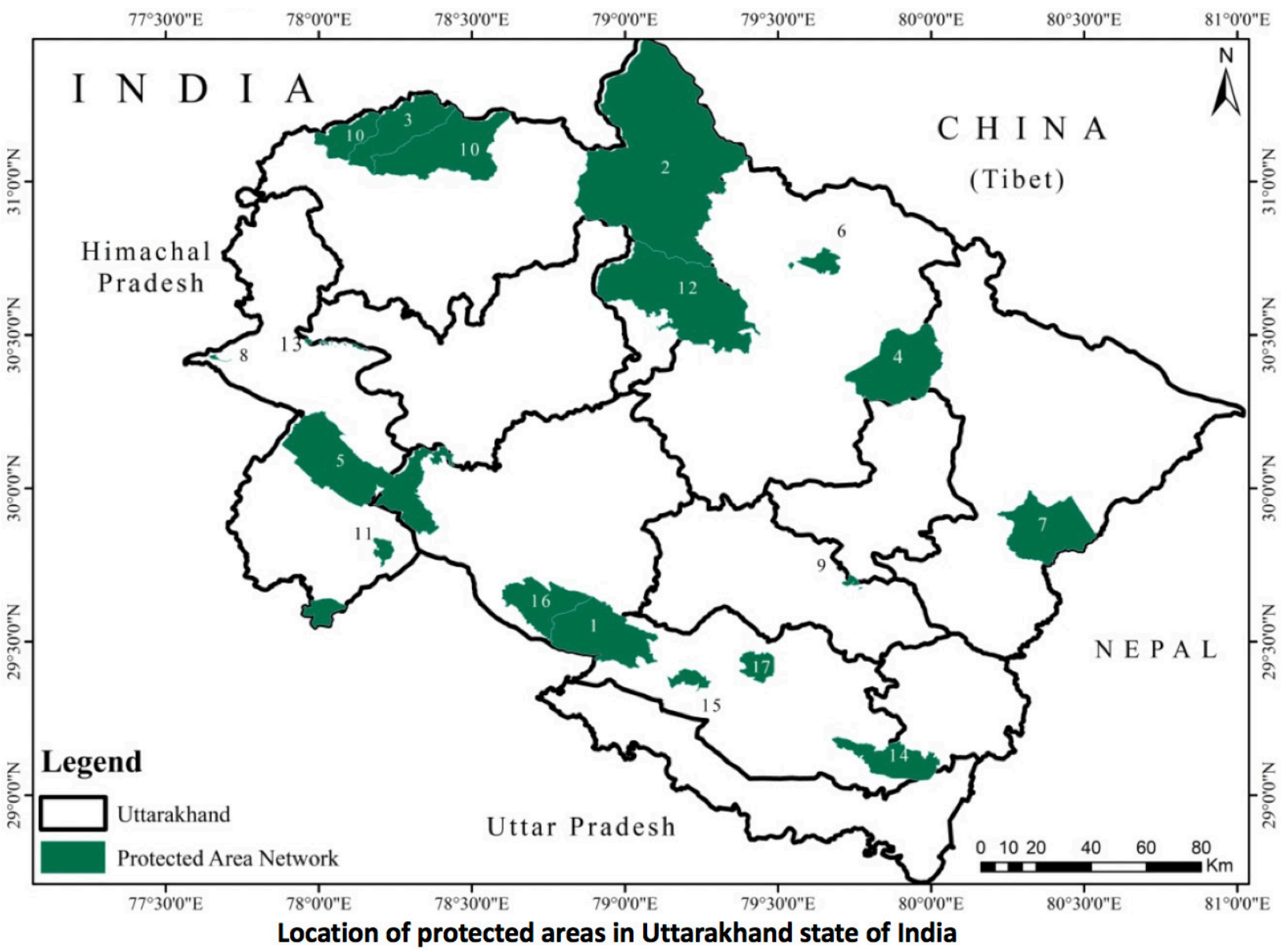


Appendix II. Vegetation compostion of forest sub-types sampled in the state taken up for study.

\begin{tabular}{|c|c|c|c|c|}
\hline & Forest sub-type & Area $\left(\mathbf{k m}^{2}\right)$ & $\begin{array}{l}\text { Percent of } \\
\text { state cover }\end{array}$ & Dominant trees \\
\hline 1 & 3C/C2a Moist Shiwalik Sal Forest & 3158 & 12.97 & $\begin{array}{l}\text { Shorea robusta, Anogeissus latifolia, Terminalia tomentosa,T.bellerica, } \\
\text { Adina cordifolia, Lannea coromandelica, Mallotus philippensis }\end{array}$ \\
\hline 2 & 3C/C2c Moist Terai Sal Forest & 542 & 2.19 & $\begin{array}{l}\text { Shorea robusta, Adina cordifolia, T.alata, Terwia nudiflora, Syzygium } \\
\text { cumini, Litsea glutinosa, Lagerstroemia parviflora, Cordia dichotoma, } \\
\text { Putranjiva roxburghii,Litsea monopetla, Pogostemon benghalensis. }\end{array}$ \\
\hline 3 & 5B/C1a Dry Shiwalik Sal Forest & 236 & 1.5 & $\begin{array}{l}\text { Shorea robusta, Anogeissus latifolia, Buchanania lanzan, Terminalia } \\
\text { tomentosa, Bauhinia variegata, Emblica officinalis, Acacia catechu, } \\
\text { Pinus roxburghii, Schleichera oleosa, Cassia fistula, Zizyphus xylopyrus(B. } \\
\text { vahlii-shrub) }\end{array}$ \\
\hline 4 & $\begin{array}{l}5 \mathrm{~B} / \mathrm{C} 2 \text { Northern Dry Mixed Deciduous } \\
\text { Forest }\end{array}$ & 678 & 2.82 & $\begin{array}{l}\text { Anogeissus latifolia, Boswellia serrata, Acacia catechu, Shorea robusta, } \\
\text { Bauhinia spp.,Bauchanania lanzan, Diospyros tomentosa, Teminalian } \\
\text { bellerica, Kydiacalycina, Sterculia Iappeus, Miytragyna parvifolia, Aegle } \\
\text { marmelos, Butea monsperma, Flacourtia indica, Zizyphus mauratina }\end{array}$ \\
\hline 5 & 5/1S2 Khair-Sissu Forest & 236 & 0.98 & $\begin{array}{l}\text { Dalbergia sissoo, Acacia catechu, Zyzyphus mauratiana, Ehretia laevis, } \\
\text { Holoptelea integrifolia. }\end{array}$ \\
\hline 6 & 9/C1b Upper or Himalayan Chir Pine Forest & 6278 & 26.07 & $\begin{array}{l}\text { Pinus roxburghii, Quercus leucotrichophora; Lyonia ovalifolia, } \\
\text { Rhododendron arboreum, Pyrus pashia, Myrica esculanta, Pyracantha } \\
\text { crenulata, Symplocos crataegoides. }\end{array}$ \\
\hline 7 & 12/C1a Ban Oak Forest & 4798 & 20.23 & $\begin{array}{l}\text { Quercus leucotrichophora, Rhododendron arboreum, Lyonia ovalifolia, } \\
\text { Rhus semialata, Symplocos crataegoides, Benthamidia capitata, Carpinus } \\
\text { viminea, Betula alnoides }\end{array}$ \\
\hline 8 & 12/C1b Moru Oak Forest & 9317 & 3.95 & $\begin{array}{l}\text { Quercus floribunda, Q.leucotrichophora, Pinus wallichiana, Betula } \\
\text { alnoides, Carpinus viminea, Acer caesium, Michilus duthei, Aesculus } \\
\text { indica, Abies pindrow, Picea smithiana, Juglans regia. }\end{array}$ \\
\hline 9 & 12/C1c Moist Deodar Forest & 485 & 1.96 & Cedrus deodara, Pinus wallichiana, Quercus leucotrichophora \\
\hline 10 & $\begin{array}{l}\text { 12/C1d Western Mixed Coniferous Forest- } \\
\text { Spruce, Blue Pine, Silver Fir }\end{array}$ & 513 & 2.19 & $\begin{array}{l}\text { Picea smithiana, Cedrus deodara, Abies pindrow, Pinus wallichiana } \\
\text { Quercus floribunda, Q.semecarpifolia, Q.leucotrichophora, Acer caesium, } \\
\text { A.pictum, A. acuminatum, Euonymus lacerus, Taxus baccata, Betula } \\
\text { alnoides. }\end{array}$ \\
\hline 11 & 12/C1e Moist Temperate Deciduous Forest & 246 & 1.07 & $\begin{array}{l}\text { Alnus nepalensis, Aesculus indica, Acer caesium, A.pictum, Carpinus } \\
\text { viminea, Ulmus wallichiana, Betula alnoides, Juglans regia, Fraxinus } \\
\text { micrantha, Quercus leucotrichophora, Q.floribunda, Q.semecarpifolia. } \\
\text { Prunus cornuta, Rhododendron arboreum. }\end{array}$ \\
\hline 12 & $\begin{array}{l}\text { 12/C2a Kharsu Oak Forest ( } Q \text {. } \\
\text { semecarpifolia) }\end{array}$ & 227 & 0.99 & $\begin{array}{l}\text { Quercus semecarpifolia, Abiespindrow, Betula alnoides, Q. floribunda, } \\
\text { Acer caesium, Ilex dipyrena, Taxus baccata. }\end{array}$ \\
\hline 13 & $\begin{array}{l}\text { 12/C } 2 \text { b West Himalayan Upper Oak/Fir } \\
\text { Forest }\end{array}$ & 1087 & 4.57 & $\begin{array}{l}\text { Abiespindrow, Piceasmithiana, Quercus semecarpifolia, Q.floribunda, } \\
\text { Pyrus lanata, Acer caesium, Meliosma dilleniaefolia, Eunonymus lacerus, } \\
\text { Ilex diprena, Sorbussoliosa, Rhododendron arboreum, R. barbatum, } \\
\text { Ulmus wallichiana, Aesc ulus indica, Corylus colurna }\end{array}$ \\
\hline 14 & 12/2S1 Low Level Blue Pine Forest & 384 & 1.54 & Pinus wallichiana, Quercus leucotrichophora \\
\hline 15 & 13/C2b Dry Deodar Forest & 363 & 1.46 & Cedrus deodara, Pinus wallichiana, Picea smithiana, Corylus colurna \\
\hline 16 & $\begin{array}{l}\text { 14/C1a West Himalayan Sub-Alpine High } \\
\text { Level Fir Forest }\end{array}$ & 195 & 0.78 & $\begin{array}{l}\text { Abies spectalilis, Pinus wallichiana, Piceasmithiana, Rhododendron } \\
\text { companulatum, Taxus baccata, Prunus padus }\end{array}$ \\
\hline 17 & $\begin{array}{l}\text { 14/C1b West Himalayan Sub-Alpine Birch/ } \\
\text { Fir Forest }\end{array}$ & 583 & 2.47 & $\begin{array}{l}\text { Abies spectabilis, Acer cappadociccum, Betula utilis, Quercus } \\
\text { semecarpifolia, Rhododendron campanulatum, R. anthopogon, Lyonia } \\
\text { ovalifolia, Sorbusfoliolosa }\end{array}$ \\
\hline 18 & 14/1S2 Deciduous Sub-Alpine Scrub & 200 & 0.86 & Betula utilis \\
\hline 19 & 15/C1 Birch/Rhododendron Scrub Forest & 136 & 0.56 & $\begin{array}{l}\text { Betula utilis, Rhododendron companulatum, Sorbus foliolosa, Quercus } \\
\text { semecarpifolia }\end{array}$ \\
\hline 20 & 15/E1 Dwarf Rhododendron Scrub & 32 & 0.13 & Rhododendron anthopogon, R. lepidotum, R. companulatum, Ilex diprena \\
\hline
\end{tabular}

Source: Champion \& Seth (1968). 
Appendix III. Complete list of butterflies sampled in 20 different forest types of Uttarakhand ranked according to their relative abundances (2006-2009 \& 2017-2020).

\begin{tabular}{|c|c|}
\hline & Butterfly species \\
\hline A. & Very Common \\
\hline 1 & Eurema hecabe (Linnaeus, 1758) \\
\hline 2 & Catopsilia pomona (Fabricius, 1775) \\
\hline 3 & Ypthima sakra sakra Moore, [1858] \\
\hline 4 & Pieris canidia indica Evans, 1926 \\
\hline 5 & Celastrina huegeli huegeli (Moore, 1882) \\
\hline 6 & Aporia agathon (Gray, 1831) \\
\hline 7 & Junonia iphita iphita (Cramer, [1779]) \\
\hline 8 & Callerebia nirmala (Moore, 1865) \\
\hline 9 & Aglais caschmirensis aesis (Fruhstorfer, 1912) \\
\hline 10 & Papilio polytes romulus Cramer, [1775] \\
\hline 11 & Pseudozizeeria maha maha (Kollar, [1844]) \\
\hline 12 & Acytolepis puspa (Horsfield, [1828]) \\
\hline 13 & Aulocera swaha swaha (Kollar, [1844]) \\
\hline 14 & Dodona durga durga (Kollar, [1844]) \\
\hline 15 & Leptosia nina (Fabricius, 1793) \\
\hline 16 & Neptis hylas varmona Moore, 1872 \\
\hline 17 & Vanessa indica indica (Herbst, 1794) \\
\hline 18 & Euploea core core (Cramer, [1780]) \\
\hline 19 & Arhopala amantes apella (Swinhoe, 1886) \\
\hline 20 & Pieris brassicae (Linnaeus, 1758) \\
\hline 21 & Neptis mahendra mahendra Moore, 1872 \\
\hline 22 & Gonepteryx rhamni nepalensis Doubleday, 1847 \\
\hline 23 & Vanessa cardui (Linnaeus, 1758) \\
\hline 24 & Celastrina lavendularis limbatus (Moore, 1879) \\
\hline 25 & Ypthima huebneri Kirby, 1871 \\
\hline 26 & Junonia lemonias lemonias (Linnaeus, 1758) \\
\hline 27 & Lethe sidonis (Hewitson, 1863) \\
\hline 28 & Ariadne merione tapestrina (Moore, 1884) \\
\hline 29 & Lasiommata schakra schakra (Kollar, [1844]) \\
\hline 30 & Symbrenthia lilaea khasiana Moore, [1875] \\
\hline 31 & Phalanta phalantha phalantha (Drury, [1773]) \\
\hline 32 & Callerebia hybrida Butler, 1880 \\
\hline 33 & Arhopala atrax (Hewitson, 1862) \\
\hline 34 & Callerebia scanda scanda (Kollar, [1844]) \\
\hline 35 & Parantica aglea melanoides Moore, 1883 \\
\hline 36 & Athyma opalina opalina Kollar, 1844 \\
\hline 37 & Heliophorus sena (Kollar, [1844]) \\
\hline 38 & Prosotas nora ardates (Moore, [1875]) \\
\hline 39 & Catopsilia pyranthe (Linnaeus, 1758) \\
\hline 40 & Colias fieldii Ménétriés, 1855 \\
\hline 41 & Ypthima nikaea Moore, [1875] \\
\hline 42 & Cepora nerissa phryne (Fabricius, 1775) \\
\hline
\end{tabular}

\begin{tabular}{|c|c|}
\hline & Butterfly species \\
\hline 43 & Danaus chrysippus chrysippus (Linnaeus, 1758) \\
\hline 44 & Lethe verma verma (Kollar, [1844]) \\
\hline 45 & Ypthima inica Hewitson, [1865] \\
\hline 46 & Ypthima baldus baldus (Fabricius, 1775) \\
\hline 47 & Pareronia hippia (Fabricius, 1787) \\
\hline 48 & Castalius rosimon rosimon (Fabricius, 1775) \\
\hline 49 & Heliophorus tamu tamu (Kollar, [1844]) \\
\hline 50 & Acraea issoria issoria (Hübner, [1819]) \\
\hline 51 & Lampides boeticus (Linnaeus, 1767) \\
\hline 52 & Cyrestis thyodamas ganescha Kollar, 1848 \\
\hline 53 & Jamides celeno celeno (Cramer, [1775]) \\
\hline 54 & Delias belladonna horsfieldi (Gray, 1831) \\
\hline 55 & Neopithecops zalmora zalmora (Butler, [1870]) \\
\hline 56 & Euploea mulciber mulciber (Cramer, [1777]) \\
\hline 57 & Euaspa milionia milionia (Hewitson, [1869]) \\
\hline 58 & Sephisa dichroa (Kollar, [1844]) \\
\hline 59 & Issoria issaea (Doherty, 1886) \\
\hline 60 & Prosotas dubiosa indica (Evans, [1925]) \\
\hline 61 & Junonia atlites atlites (Linnaeus, 1763) \\
\hline 62 & Callerebia annada caeca (Watkins, 1925) \\
\hline 63 & Ypthima nareda (Kollar, [1844]) \\
\hline 64 & Danaus genutia genutia (Cramer, [1779]) \\
\hline 65 & Papilio demoleus demoleus Linnaeus, 1758 \\
\hline 66 & Mycalesis perseus blasius Fabricius, 1798 \\
\hline 67 & Arhopala ganesa ganesa (Moore, [1858]) \\
\hline 68 & Colias erate (Esper, 1805) \\
\hline 69 & Eurema blanda (Boisduval, 1836) \\
\hline 70 & Junonia hierta hierta (Fabricius, 1798) \\
\hline 71 & Parantica sita sita (Kollar, [1844]) \\
\hline 72 & Zizeeria karsandra (Moore, 1865) \\
\hline 73 & Cupha erymanthis lotis (Sulzer, 1776) \\
\hline 74 & Athyma perius perius (Linnaeus, 1758) \\
\hline 75 & Kaniska canace canace (Linnaeus, 1763) \\
\hline 76 & Ixias pyrene (Linnaeus, 1764) \\
\hline 77 & Zizina otis otis (Fabricius, 1787) \\
\hline 78 & Hypolimnas bolina jacintha (Drury, 1773) \\
\hline 79 & Chrysozephyrus birupa Moore, 1877 \\
\hline 80 & Acraea terpsicore (Linnaeus, 1758) \\
\hline 81 & Lycaena phlaeas baralacha (Moore, 1884) \\
\hline 82 & Delias eucharis (Drury, 1773) \\
\hline 83 & Celaenorrhinus leucocera (Kollar, [1844]) \\
\hline 84 & Junonia almana almana (Linnaeus, 1758) \\
\hline 85 & Junonia orithya (Linnaeus, 1758) \\
\hline
\end{tabular}




\begin{tabular}{|c|c|c|c|}
\hline & Butterfly species & & Butterfly species \\
\hline 86 & Pelopidas mathias mathias (Fabricius, 1798) & 130 & Aporia leucodice (Eversmann, 1843) \\
\hline 87 & Melanitis leda leda (Linnaeus, 1758) & 131 & Polytremis eltola eltola (Hewitson, 1869) \\
\hline 88 & Charaxes bharata C. \& R. Felder, [1867] & 132 & Symbrenthia hypselis cotanda Moore, [1875] \\
\hline 89 & Argynnis childreni sakontala Kollar, [1848] & 133 & Megisba malaya sikkima Moore, 1884 \\
\hline 90 & Esakiozephyrus icana icana (Moore, [1875]) & 134 & Neptis ananta ananta Moore, [1858] \\
\hline 91 & Libythea lepita lepita Moore, [1858] & 135 & Graphium nomius nomius (Esper, 1799) \\
\hline B. & Common & 136 & Belenois aurota aurota (Fabricius, 1793) \\
\hline 92 & Euthalia patala patala (Kollar, [1844]) & 137 & Pseudergolis wedah wedah (Kollar, [1844]) \\
\hline 93 & Pantoporia hordonia hordonia (Stoll, [1790]) & 138 & Arhopala dodonaea (Moore, [1858]) \\
\hline 94 & Orinoma damaris damaris Gray, 1846 & 139 & Chilades lajus lajus (Stoll, [1780]) \\
\hline 95 & Tanaecia lepidea lepidea (Butler, 1868) & 140 & Poritia hewitsoni hewitsoni Moore, [1866] \\
\hline 96 & Chilades pandava pandava (Horsfield, [1829] & 141 & Pieris melete ajaka Moore, 1865 \\
\hline 97 & Papilio protenor protenor Cramer, [1775] & 142 & Lethe isana isana (Kollar, [1844]) \\
\hline 98 & Lycaena panava (Westwood, 1852) & 143 & Leptotes plinius plinius (Fabricius, 1793) \\
\hline 99 & Talicada nyseus nyseus (Guérin-Méneville, 1843) & 144 & Neptis sankara sankara (Kollar, [1844]) \\
\hline 100 & Oriens gola pseudolus (Mabille, 1883) & 145 & Rapala nissa nissa (Kollar, [1844]) \\
\hline 101 & Dodona dipoea nostia Fruhstorfer, 1912 & 146 & Byasa latreillei latreillei (Donovan, 1826) \\
\hline 102 & Moduza procris (Cramer, [1777]) & 147 & Lethe nicetas (Hewitson, 1863) \\
\hline 103 & Rapala manea schistacea (Moore, 1879) & 148 & Tirumala septentrionis septentrionis (Butler, 1874) \\
\hline 104 & Pseudocoladenia fatih (Kollar, [1844]) & 149 & Parnara guttatus mangala (Moore, [1866]) \\
\hline 105 & Byasa polyeuctes letincius (Fruhstorfer, 1908) & 150 & Eurema andersonii jordani Corbet \& Pendlebury, 1932 \\
\hline 106 & Elymnias hypermnestra undularis (Drury, 1773) & 151 & Stibochiona nicea nicea (Gray, 1846) \\
\hline 107 & Euthalia lubentina lubentina (Cramer, [1777]) & 152 & Auzakia danava danava (Moore, [1858]) \\
\hline 108 & Zemeros flegyas flegyas (Cramer, [1780] & 153 & Celaenorrhinus patula de Nicéville, 1889 \\
\hline 109 & Rhaphicera moorei moorei (Butler, 1867) & 154 & Pelopidas assamensis (de Nicéville, 1882) \\
\hline 110 & Callerebia hyagriva hyagriva (Moore, [1858]) & 155 & Symphaedra nais (Forster, 1771) \\
\hline 111 & Hypolycaena othona othona Hewitson, [1865] & 156 & Abisara fylla (Westwood, [1851]) \\
\hline 112 & Dodona eugenes Bates, [1868] & 157 & Graphium sarpedon sarpedon (Linnaeus, 1758) \\
\hline 113 & Sarangesa dasahara (Moore, [1866]) & 158 & Troides aeacus (C. \& R. Felder, 1860) \\
\hline 114 & Eurema brigitta rubella (Wallace, 1867) & 159 & Hestinalis nama nama (Doubleday, 1844) \\
\hline 115 & Mycalesis mineus mineus (Linnaeus, 1758) & 160 & Neptis nata yerburii Butler, 1886 \\
\hline 116 & Abisara bifasciata suffusa Moore, 1882 & 161 & Vagrans egista sinha (Kollar, [1844]) \\
\hline 117 & Euthalia aconthea garuda (Moore, [1858]) & 162 & Heliophorus oda (Hewitson, 1865) \\
\hline 118 & Rapala varuna orseis (Hewitson, [1863]) & 163 & Oriens goloides (Moore, [1881]) \\
\hline 119 & Graphium cloanthus cloanthus (Westwood, 1841) & 164 & Argynnis hyperbius hyperbius (Linnaeus, 1763) \\
\hline 120 & Curetis acuta dentata Moore, 1879 & 165 & Tirumala limniace exoticus (Gmélin, 1790) \\
\hline 121 & Heliophorus moorei coruscans (Moore, 1882) & 166 & Udara albocaeruleus albocaeruleus (Moore, 1879) \\
\hline 122 & Notocrypta curvifascia curvifascia (C. \& R. Felder, 1862) & 167 & Zizula hylax hylax (Fabricius, 1775) \\
\hline 123 & Eurema laeta laeta (Boisduval, 1836) & 168 & Matapa aria (Moore, [1866]) \\
\hline 124 & Celatoxia marginata marginata (de Nicéville, [1884]) & 169 & Pachliopta aristolochiae aristolochiae (Fabricius, 1775) \\
\hline 125 & Papilio bianor polyctor Boisduval, 1836 & 170 & Athyma selenophora selenophora (Kollar, [1844]) \\
\hline 126 & Lethe confusa confusa Aurivillius, [1898] & 171 & Lethe europa niladana Fruhstorfer, 1911 \\
\hline 127 & Lethe dura gammiei (Moore, [1892]) & 172 & Libythea myrrha sanguinalis Fruhstorfer, 1898 \\
\hline 128 & Kallima inachus inachus (Doyère, [1840]) & 173 & Ypthima asterope mahratta Moore, 1884 \\
\hline 129 & Catochrysops strabo strabo (Fabricius, 1793) & 174 & Tarucus indica Evans, 1932 \\
\hline
\end{tabular}




\begin{tabular}{|c|c|}
\hline & Butterfly species \\
\hline 175 & Udara dilectus dilectus (Moore, 1879) \\
\hline 176 & Borbo cinnara (Wallace, 1866) \\
\hline 177 & Pelopidas subochracea (Moore, 1878) \\
\hline 178 & Ixias marianne (Cramer, [1779]) \\
\hline 179 & Argynnis kamala Moore, [1858] \\
\hline 180 & Telinga heri (Moore, [1858]) \\
\hline 181 & Taractrocera danna (Moore, 1865) \\
\hline 182 & Telicota bambusae bambusae (Moore, 1878) \\
\hline 183 & Chrysozephyrus syla Kollar, 1848 \\
\hline 184 & Lobocla liliana ignatius (Plötz, 1882) \\
\hline 185 & Pelopidas sinensis (Mabille, 1877) \\
\hline c. & Fairly Common (Median) \\
\hline 186 & Delias sanaca sanaca(Moore, [1858]) \\
\hline 187 & Pontia daplidice moorei (Röber, [1907]) \\
\hline 188 & Lethe rohria rohria (Fabricius, 1787) \\
\hline 189 & Tagiades litigiosa litigiosa Möschler, 1878 \\
\hline 190 & Aulocera saraswati saraswati (Kollar, [1844]) \\
\hline 191 & Mycalesis visala visala Moore, [1858] \\
\hline 192 & Neptis melba melba Evans, 1912 \\
\hline 193 & Symbrenthia brabira brabira Moore, 1872 \\
\hline 194 & Everes argiades diporides Chapman, 1908 \\
\hline 195 & Jamides bochus bochus (Stoll, [1782]) \\
\hline 196 & Tarucus nara (Kollar, 1848) \\
\hline 197 & Papilio machaon Linnaeus, 1758 \\
\hline 198 & Hypolimnas misippus (Linnaeus, 1764) \\
\hline 199 & Spialia galba galba (Fabricius, 1793) \\
\hline 200 & Papilio clytia clytia Linnaeus, 1758 \\
\hline 201 & Melanitis phedima bela Moore, [1858] \\
\hline 202 & Tarucus venosus Moore, 1882 \\
\hline 203 & Athyma cama cama Moore, [1858] \\
\hline 204 & Celastrina gigas (Hemming, 1928) \\
\hline 205 & Byasa dasarada ravana (Moore, [1858]) \\
\hline 206 & Neptis sappho astola Moore, 1872 \\
\hline 207 & Loxura atymnus continentalis Fruhstorfer, [1912] \\
\hline 208 & Oreolyce vardhana vardhana (Moore, [1875]) \\
\hline 209 & Shizuyaozephyrus ziha (Hewitson, [1865]) \\
\hline 210 & Surendra quercetorum quercetorum (Moore, [1858]) \\
\hline 211 & Graphium agamemnon agamemnon (Linnaeus, 1758) \\
\hline 212 & Neope yama buckleyi Talbot, 1947 \\
\hline 213 & Neptis clinia praedicta Smetacek, 2011 \\
\hline 214 & Phaedyma columella ophiana (Moore, 1872) \\
\hline 215 & Everes lacturnus assamica Tytler, 1915 \\
\hline 216 & Horaga onyx onyx (Moore, [1858]) \\
\hline 217 & Atrophaneura varuna astorion (Westwood, 1842) \\
\hline 218 & Euripus consimilis consimilis (Westwood, [1851]) \\
\hline
\end{tabular}

\begin{tabular}{|c|c|}
\hline & Butterfly species \\
\hline 219 & Neope pulaha pandyia (Talbot, 1947) \\
\hline 220 & Telinga lepcha lepcha (Moore, 1880) \\
\hline 221 & Arhopala rama rama (Kollar, [1844]) \\
\hline 222 & Euchrysops cnejus cnejus (Fabricius, 1798) \\
\hline 223 & Spindasis vulcanus vulcanus (Fabricius, 1775) \\
\hline 224 & Notocrypta feisthamelii alysos (Moore, [1866]) \\
\hline 225 & Telicota colon colon (Fabricius, 1775) \\
\hline 226 & Parnassius hardwickei Gray, 1831 \\
\hline 227 & Neptis cartica cartica Moore, 1872 \\
\hline 228 & Rapala iarbus sorya (Kollar, [1844]) \\
\hline 229 & Papilio paris paris Linnaeus, 1758 \\
\hline 230 & Athyma asura asura Moore, [1858] \\
\hline 231 & Aricia agestis nazira (Moore, [1866]) \\
\hline 232 & Deudorix epijarbas epijarbas (Moore, [1858]) \\
\hline 233 & Rapala selira (Moore, 1874) \\
\hline 234 & Burara jaina jaina (Moore, [1866]) \\
\hline 235 & lambrix salsala salsala (Moore, [1866]) \\
\hline 236 & Meandrusa lachinus lachinus (Fruhstorfer, 1902) \\
\hline 237 & Papilio agestor govindra Moore, 1864 \\
\hline 238 & Charaxes bernardus hierax C. \& R. Felder, [1867] \\
\hline 239 & Mycalesis francisca sanatana Moore, [1858] \\
\hline 240 & Neptis soma butleri Eliot, 1969 \\
\hline 241 & Neptis zaida zaida Doubleday, [1848] \\
\hline 242 & Hypolycaena kina kina Hewitson, [1869] \\
\hline 243 & Borbo bevani (Moore, 1878) \\
\hline 244 & Sarangesa purendra purendra Moore, 1882 \\
\hline 245 & Graphium eurous caschmirensis (Rothschild, 1895) \\
\hline 246 & Hestina persimilis zella Butler, 1869 \\
\hline 247 & Paralasa kalinda kalinda Moore, 1865 \\
\hline 248 & Polygonia c-album cognata Moore, [1899] \\
\hline 249 & Telinga nicotia (Westwood, [1850]) \\
\hline 250 & Freyeria trochylus orientalis Forster, 1980 \\
\hline 251 & Pratapa icetas icetas (Hewitson, [1865]) \\
\hline 252 & Caprona agama agama (Moore, [1858]) \\
\hline 253 & Celaenorrhinus munda (Moore, 1884) \\
\hline 254 & Celaenorrhinus pulomaya pulomaya (Moore, [1866]) \\
\hline 255 & Suastus gremius gremius (Fabricius, 1798) \\
\hline 256 & Udaspes folus (Cramer, [1775]) \\
\hline 257 & Ypthima kedarnathensis Singh, 2007 \\
\hline 258 & Heliophorus brahma brahma (Moore, [1858]) \\
\hline 259 & Ampittia dioscorides dioscorides (Fabricius, 1793) \\
\hline 260 & Burara oedipodea belesis (Mabille, 1876) \\
\hline 261 & Sovia lucasii (Mabille, 1876) \\
\hline 262 & Polytremis discreta discreta (Elwes \& Edwards, 1897) \\
\hline 263 & Papilio arcturus arius Rothschild, 1908 \\
\hline
\end{tabular}




\begin{tabular}{|c|c|c|c|}
\hline & Butterfly species & & Butterfly species \\
\hline 264 & Dilipa morgiana (Westwood, [1851]) & 308 & Baoris farri (Moore, 1878) \\
\hline 265 & Nymphalis xanthomelas fervescens (Stichel, [1908]) & 309 & Bibasis sena sena (Moore, [1866]) \\
\hline 266 & Celastrina argiolus kollari (Westwood, [1852]) & 310 & Atrophaneura aidoneus (Doubleday, 1845) \\
\hline 267 & Spindasis ictis ictis (Hewitson, 1865) & 311 & Graphium garhwalica (Katayama, 1988) \\
\hline 268 & Zesius chrysomallus Hübner, [1819] & 312 & Aporia agathon caphusa (Moore, 1872) \\
\hline 269 & Caprona ransonnettii potiphera (Hewitson, 1873) & 313 & Gonepteryx mahaguru mahaguru Gistel, 1857 \\
\hline 270 & Potanthus dara (Kollar, [1844]) & 314 & Ariadne ariadne pallidior (Fruhstorfer, 1899) \\
\hline 271 & Tagiades menaka menaka (Moore, [1866]) & 315 & Charaxes solon solon (Fabricius, 1793) \\
\hline 272 & Tarucus callinara (Butler, 1886) & 316 & Pantoporia sandaka davidsoni Eliot, 1969 \\
\hline 273 & Anthene emolus emolus (Godart, [1824]) & 317 & Tanaecia julii appiades (Ménétriés, 1857) \\
\hline D. & Uncommon & 318 & Ypthima avanta Moore, [1875] \\
\hline 274 & Aulocera brahminus (Blanchard, 1853) & 319 & Flos asoka (de Nicéville, [1884]) \\
\hline 275 & Symbrenthia niphanda hysudra Moore, 1874 & 320 & Petrelaea dana (de Nicéville, [1884]) \\
\hline 276 & Freyeria putli (Kollar, [1844]) & 321 & Rapala pheretima petosiris (Hewitson, [1863]) \\
\hline 277 & Iraota timoleon timoleon (Stoll, [1790]) & 322 & Sinthusa chandrana chandrana (Moore, 1882) \\
\hline 278 & Tajuria cippus cippus (Fabricius, 1798) & 323 & Spalgis epius epius (Westwood, [1851]) \\
\hline 279 & Tajuria diaeus diaeus (Hewitson, [1865]) & 324 & Virachola isocrates (Fabricius, 1793) \\
\hline 280 & Choaspes benjaminii japonica (Murray, 1875) & 325 & Dodona ouida phlegra Fruhstorfer, 1914 \\
\hline 281 & Hyarotis adrastus praba (Moore, [1866]) & 326 & Celaenorrhinus pero pero de Nicéville, 1889 \\
\hline 282 & Pelopidas conjuncta conjuncta (Herrich-Schäffer, 1869) & 327 & Coladenia indrani indrani (Moore, [1866]) \\
\hline 283 & Graphium doson axionides (Page \& Treadaway, 2014) & 328 & Ochlodes brahma (Moore, 1878) \\
\hline 284 & Aporia agathon phryxe (Boisduval, 1836) & 329 & Odontoptilum angulata angulata (C. Felder, 1862) \\
\hline 285 & Charaxes dolon dolon Westwood, [1848] & 330 & Seseria dohertyi dohertyi (Watson, 1893) \\
\hline 286 & Mimathyma ambica ambica (Kollar, [1844]) & 331 & Taractrocera maevius (Fabricius, 1793) \\
\hline 287 & Ypthima indecora Moore, 1882 & 332 & Papilio alcmenor alcmenor C. \& R. Felder, [1864] \\
\hline 288 & Ancema ctesia ctesia (Hewitson, [1865]) & 333 & Papilio memnon agenor Linnaeus, 1758 \\
\hline 289 & Chaetoprocta odata peilei Forster, 1980 & 334 & Parnassius epaphus Oberthür, 1879 \\
\hline 290 & Curetis bulis bulis (Westwood, [1851]) & 335 & Appias lalage (Doubleday, 1842) \\
\hline 291 & Thermozephyrus ataxus ataxus (Westwood, [1851]) & 336 & Appias libythea (Fabricius, 1775) \\
\hline 292 & Virachola perse perse (Hewitson, [1863]) & 337 & Aglais rizana (Moore, 1872) \\
\hline 293 & Aeromachus stigmata stigmata (Moore, 1878) & 338 & Athyma inara inara Westwood, 1850 \\
\hline 294 & Celaenorrhinus dhanada (Moore, [1866]) & 339 & Euploea midamus (Linnaeus, 1758) \\
\hline 295 & Tagiades japetus ravi (Moore, [1866]) & 340 & Hyponephele pulchella (C. \& R. Felder, [1867]) \\
\hline 296 & Gandaca harina assamica Moore, 1906 & 341 & Lethe dakwania Tytler, 1939 \\
\hline 297 & Neptis narayana Moore, 1858 & 342 & Mycalesis suaveolens ranotei Smetacek, 2012 \\
\hline 298 & Ypthima hannyngtoni hannyngtoniEliot, 1967 & 343 & Everes hugelii hugelii (Gistel, 1857) \\
\hline 299 & Arhopala paraganesa paraganesa (de Nicéville, 1882) & 344 & Heliophorus indicus (Fruhstorfer, 1908) \\
\hline 300 & Azanus ubaldus (Stoll, [1782]) & 345 & Horaga viola Moore, 1882 \\
\hline 301 & Aeromachus dubius Elwes \& Edwards, 1897 & 346 & Pratapa deva lila Moore, [1884] \\
\hline 302 & Badamia exclamationis (Fabricius, 1775) & 347 & Spindasis elima uniformis (Moore, 1882) \\
\hline 303 & Argynnis jainadeva jainadeva Moore, 1864 & 348 & Tajuria jehana jehana Moore, [1884] \\
\hline 304 & Aulocera padma padma (Kollar, [1844]) & 349 & Baoris pagana (de Nicéville, 1887) \\
\hline 305 & Lethe baladeva aisa Fruhstorfer, 1911 & 350 & Caltoris kumara (Moore, 1878) \\
\hline 306 & Lethe sinorix sinorix (Hewitson, [1863]) & 351 & Erionota torus Evans, 1941 \\
\hline 307 & Spindasis nipalicus (Moore, 1884) & 352 & Pedesta masuriensis masuriensis (Moore, 1878) \\
\hline
\end{tabular}




\begin{tabular}{|l|l|}
\hline & Butterfly species \\
\hline 353 & Sovia grahami grahami (Evans, 1926) \\
\hline 354 & Papilio bootes janaka Moore, 1857 \\
\hline 355 & Papilio helenus helenus Linnaeus, 1758 \\
\hline 356 & Parnassius charltonius Gray, [1853] \\
\hline 357 & Colotis etrida (Boisduval, 1836) \\
\hline 358 & Delias acalis pyramus (Wallace, 1867) \\
\hline 359 & Charaxes agrarius Swinhoe, [1887] \\
\hline 360 & Hyponephele davendra davendra (Moore, 1865) \\
\hline 361 & Lethe goalpara goalpara (Moore, [1866]) \\
\hline 362 & Polygonia c-album agnicula (Moore, 1872) \\
\hline 363 & Ypthima parasakra Eliot, 1987 \\
\hline
\end{tabular}

\begin{tabular}{|l|l|}
\hline & Butterfly species \\
\hline 364 & Heliophorus epicles latilimbata (Fruhstorfer, 1908) \\
\hline 365 & Miletus chinensis assamensis (Doherty, 1891) \\
\hline 366 & Spindasis lohita himalayanus (Moore, 1884) \\
\hline 367 & Hasora chromus (Cramer, [1780]) \\
\hline 368 & Thoressa aina (de Nicéville, 1889) \\
\hline 369 & Maneca bhotea bhotea (Moore, 1884) \\
\hline 370 & Celaenorrhinus pyrrha de Nicéville, 1889 \\
\hline
\end{tabular}

The relative abundance of butterfly taxa ranging from 1-1,596 individuals. The taxa are ranked into four abundance classes based on their quartile divisions, i.e., Q1= 1-7 Uncommon; Q2= 8-21= Fairly Common;

$\mathrm{Q} 3=22-69=$ Common; $\mathrm{Q} 4=70-1,596=$ Very Common

Median value $=21$

Appendix IV. Butterfly taxa of conservation priority in Uttarakhand.

\begin{tabular}{|c|c|c|c|c|c|c|c|}
\hline & Family/Scientific name & Common name & Distribution & $\begin{array}{c}\text { Associated } \\
\text { forest sub- } \\
\text { type* }\end{array}$ & $\begin{array}{l}\text { Abundance } \\
\text { status }\end{array}$ & WPA status & $\begin{array}{l}\text { Altitudinal } \\
\text { distribution } \\
\text { (m) }\end{array}$ \\
\hline A & \multicolumn{7}{|l|}{ PAPILLIONIDAE } \\
\hline 1 & $\begin{array}{l}\text { Byasa dasara daravana (Moore, } \\
\text { [1858]) }\end{array}$ & Great Windmill & $\mathrm{WH} ; \mathrm{CH}$ & $\begin{array}{c}\text { 12C1a; } 12 / \\
\text { C1b }\end{array}$ & NR & NA & $150-2750$ \\
\hline 2 & $\begin{array}{l}\text { Graphium eurous caschmirensis } \\
\text { (Rothschild, 1895) }\end{array}$ & Six-bar Swordtail & $\mathrm{WH} ; \mathrm{CH}$ & $12 \mathrm{C} 1 \mathrm{a}$ & NR & NA & $1000-2800$ \\
\hline 3 & $\begin{array}{l}\text { Graphium garhwalica (Katayama, } \\
\text { 1988) }\end{array}$ & Garhwal Swordtail & WH & $12 \mathrm{C} 1 \mathrm{a}$ & $\mathrm{R}$ & NA & $1600-2300$ \\
\hline 4 & Parnassius charltonius Gray, [1853] & Regal Apollo & WH; PA & $12 \mathrm{C} 1 \mathrm{a}$ & $\mathrm{R}$ & NA & $3600-4400$ \\
\hline B & \multicolumn{7}{|l|}{ PIERIDAE } \\
\hline 5 & $\begin{array}{l}\text { Aporia agathon caphusa (Moore, } \\
\text { 1872) }\end{array}$ & $\begin{array}{l}\text { Garhwal Great } \\
\text { Blackvein }\end{array}$ & $\mathrm{WH} ; \mathrm{CH}$ & 14/C1a & NR & NA & $1200-3050$ \\
\hline 6 & $\begin{array}{l}\text { Aporia agathon phryxe (Boisduval, } \\
\text { 1836) }\end{array}$ & $\begin{array}{l}\text { Kashmir Great } \\
\text { Blackvein }\end{array}$ & WH & $12 \mathrm{C} 1 \mathrm{a}$ & NR & NA & Up to 2100 \\
\hline 7 & Delias acalis pyramus (Wallace, 1867) & Redbreast Jezebel & $\mathrm{WH} ; \mathrm{CH}$ & $3 \mathrm{C} / \mathrm{C} 2 \mathrm{a}$ & NR & NA & Up to 1500 \\
\hline 8 & Delias sanaca sanaca (Moore, [1858]) & Pale Jezebel & WH & $\begin{array}{l}\text { 12/C1a; } 12 / \\
\text { C1b }\end{array}$ & NR & Sch-1 & $1200-3000$ \\
\hline 9 & $\begin{array}{l}\text { Gonepteryx mahaguru mahaguru } \\
\text { Gistel, } 1857\end{array}$ & Lesser Brimstone & $\mathrm{WH} ; \mathrm{CH}$ & $\begin{array}{c}12 / \mathrm{C} 1 \mathrm{a} ; 12 / \\
\mathrm{C} 2 \mathrm{c}\end{array}$ & NR & NA & Above 2100 \\
\hline C & \multicolumn{7}{|l|}{ NYMPHALIDAE } \\
\hline 10 & Aglais rizana (Moore, 1872) & $\begin{array}{l}\text { Mountain } \\
\text { Tortoiseshell }\end{array}$ & WH; EH & $14 / 1 S 2$ & $\mathrm{R}$ & Sch-II & $2400-4500$ \\
\hline 11 & Lethe dura gammiei (Moore, [1892]) & Scarce Lilacfork & WH; EH & $\begin{array}{c}12 / \mathrm{C} 1 \mathrm{a} ; 12 / \\
\mathrm{C} 2 \mathrm{~b}\end{array}$ & VR & Sch -1 & $1800-2200$ \\
\hline 12 & $\begin{array}{l}\text { Polygonia c-album agnicula (Moore, } \\
\text { 1872) }\end{array}$ & Nepalese Comma & $\mathrm{WH} ; \mathrm{CH} ; \mathrm{EH}$ & 14/C1a & $\mathrm{R}$ & Sch-II & $2200-4500$ \\
\hline 13 & $\begin{array}{l}\text { Ypthima parasakra parasakra Eliot, } \\
1987\end{array}$ & Dubious Five-ring & $\mathrm{WH} ; \mathrm{CH} ; \mathrm{EH}$ & $12 / 2 S 1$ & $\mathrm{R}$ & NA & $2000-2700$ \\
\hline 14 & $\begin{array}{l}\text { Argynnis jainadeva jainadeva Moore, } \\
1864\end{array}$ & HighbrownSilverspot & $\mathrm{WH} ; \mathrm{CH}$ & 14/C1a & NR & NA & $2400-4700$ \\
\hline 15 & $\begin{array}{l}\text { Callerebia hyagriva hyagriva (Moore, } \\
\text { [1858]) }\end{array}$ & Brown Argus & WH & 9/C1b & $\mathrm{R}$ & Sch-II & $1500-2400$ \\
\hline 16 & $\begin{array}{l}\text { Callerebia scanda scanda (Kollar, } \\
\text { [1844]) }\end{array}$ & Pallid Argus & WH & $\begin{array}{c}\text { 12/C1a; } 12 / \\
\text { C1b; } 12 / \\
\text { C1d }\end{array}$ & NR & NA & $1200-2800$ \\
\hline 17 & $\begin{array}{l}\text { Charaxes dolon dolon Westwood, } \\
\text { [1848] }\end{array}$ & Stately Nawab & $\mathrm{WH} ; \mathrm{CH}$ & $\begin{array}{l}\text { 12/C1a; 9/ } \\
\text { C1b }\end{array}$ & $\mathrm{R}$ & Sch - II & $1430-1900$ \\
\hline 18 & Euthalia patala patala (Kollar, [1844]) & Grand Duchess & WH & 12/C1a & NR & NA & $400-2500$ \\
\hline 19 & Hestina persimilis zellaButler, 1869 & Siren & WH & $\begin{array}{c}12 / \mathrm{C} 1 \mathrm{a} ; 3 \mathrm{C} / \\
\mathrm{C} 2 \mathrm{a}\end{array}$ & $\mathrm{R}$ & Sch - II & $750-1460$ \\
\hline
\end{tabular}




\begin{tabular}{|c|c|c|c|c|c|c|c|}
\hline & Family/Scientific name & Common name & Distribution & $\begin{array}{c}\text { Associated } \\
\text { forest sub- } \\
\text { type* }\end{array}$ & $\begin{array}{l}\text { Abundance } \\
\text { status }\end{array}$ & WPA status & $\begin{array}{l}\text { Altitudinal } \\
\text { distribution } \\
\text { (m) }\end{array}$ \\
\hline 20 & $\begin{array}{l}\text { Hyponephele davendra davendra } \\
\text { (Moore, 1865) }\end{array}$ & $\begin{array}{l}\text { White-ringed } \\
\text { Meadowbrown }\end{array}$ & WH; PA & $12 / \mathrm{C} 1 \mathrm{c}$ & $\mathrm{R}$ & Sch -II & $900-2400$ \\
\hline 21 & $\begin{array}{l}\text { Hyponephe lepulchella (C. \& R. Felder, } \\
\text { [1867]) }\end{array}$ & $\begin{array}{l}\text { Tawny } \\
\text { Meadowbrown }\end{array}$ & WH; PA & $12 / \mathrm{c} 2 \mathrm{~b}$ & NR & NA & $3000-3600$ \\
\hline 22 & Lethe baladeva aisa Fruhstorfer, 1911 & Treble Silverstripe & $\mathrm{WH} ; \mathrm{CH}$ & $\begin{array}{l}\text { 12/C1a; } 12 / \\
\text { C2c }\end{array}$ & $\mathrm{R}$ & Sch -II & $1800-2200$ \\
\hline 23 & Lethe dakwania Tytler, 1939 & $\begin{array}{l}\text { White-wedged } \\
\text { Woodbrown }\end{array}$ & WH & $12 / C 2 c$ & $\mathrm{R}$ & NA & $2300-3900$ \\
\hline 24 & $\begin{array}{l}\text { Lethe goalpara goalpara (Moore, } \\
\text { [1866]) }\end{array}$ & Large Goldenfork & $\mathrm{WH} ; \mathrm{CH}$ & $12 / \mathrm{C} 2 \mathrm{c}$ & $\mathrm{R}$ & Sch-II & $1800-3000$ \\
\hline 25 & Lethe isana isana (Kollar, [1844]) & Common Forester & WH & $\begin{array}{l}\text { 12/C1a; } 12 / \\
\mathrm{C} 1 \mathrm{~d} ; 9 / \mathrm{C} 1 \mathrm{~b}\end{array}$ & $\mathrm{R}$ & NA & $1500-2700$ \\
\hline 26 & $\begin{array}{l}\text { Mycalesis suaveolens ranotei } \\
\text { Smetacek, } 2012\end{array}$ & $\begin{array}{l}\text { Wood-Mason's } \\
\text { Bushbrown }\end{array}$ & $\mathrm{WH} ; \mathrm{CH}$ & 12/C1a & $\mathrm{R}$ & Sch-II & $1700-2133$ \\
\hline 27 & Neope pulaha pandyia (Talbot, 1947) & Veined Labyrinth & WH & $\begin{array}{l}12 / \mathrm{C} 1 \mathrm{a} ; 12 / \\
\mathrm{C} 2 \mathrm{c} ; 12 / 2 \mathrm{~S} 1\end{array}$ & $\mathrm{R}$ & Sch-II & $1500-3050$ \\
\hline 28 & Neope yama buckleyi Talbot, 1947 & Dusky Labyrinth & $\mathrm{WH} ; \mathrm{CH}$ & $\begin{array}{c}\text { 12/C1a; } 12 / \\
\text { C2c }\end{array}$ & NR & Sch-II & $1200-2370$ \\
\hline 29 & Neptis anantaananta Moore, [1858] & Yellow Sailer & WH & $\begin{array}{c}\text { 12/C1a; } 12 / \\
\text { C2c }\end{array}$ & $\mathrm{R}$ & NA & $400-2300$ \\
\hline 30 & Neptis clinia praedicta Smetacek, 2011 & Sullied Sailer & WH & $\begin{array}{l}3 \mathrm{C} / \mathrm{C} 2 \mathrm{a} ; 3 \mathrm{C} / \\
\mathrm{C} 2 \mathrm{c} ; 12 / \mathrm{C} 1 \mathrm{a}\end{array}$ & NR & NA & Low \\
\hline 31 & $\begin{array}{l}\text { Neptis sankara sankara (Kollar, } \\
{[1844] \text { ) }}\end{array}$ & Broad-banded Sailer & WH & $\begin{array}{l}3 \mathrm{C} / \mathrm{C} 2 \mathrm{a} ; 5 \mathrm{~B} / \\
\mathrm{C} 2 ; 12 / \mathrm{C} 1 \mathrm{a}\end{array}$ & NR & NA & $800-2500$ \\
\hline 32 & Neptis Zaida Zaida Doubleday, [1848] & Pale Green Sailer & $\mathrm{WH} ; \mathrm{CH}$ & $\begin{array}{l}3 \mathrm{C} / \mathrm{C} 2 \mathrm{a} ; 12 / \\
\mathrm{C} 1 \mathrm{a}\end{array}$ & $\mathrm{R}$ & Sch-II & $900-2500$ \\
\hline 33 & $\begin{array}{l}\text { Nymphalis xanthomelas fervescens } \\
\text { (Stichel, [1908]) }\end{array}$ & Large Tortoiseshell & $\mathrm{WH} ; \mathrm{CH}$ & $\begin{array}{c}12 / \mathrm{C} 1 \mathrm{a} ; 12 / \\
\mathrm{C} 2 \mathrm{~b} ; 14 / \\
\mathrm{C} 1 \mathrm{a}\end{array}$ & NR & NA & $900-3200$ \\
\hline 34 & Paralasa kalinda kalinda Moore, 1865 & $\begin{array}{l}\text { Scarce Mountain } \\
\text { Argus }\end{array}$ & WH & $\begin{array}{l}3 \mathrm{C} / \mathrm{C} 2 \mathrm{a} ; 3 \mathrm{C} / \\
\mathrm{C} 2 \mathrm{c} ; 12 / \mathrm{C} 1 \mathrm{a}\end{array}$ & $\mathrm{R}$ & NA & $2700-3900$ \\
\hline 35 & $\begin{array}{l}\text { Polygonia c-album cognataMoore, } \\
\text { [1899] }\end{array}$ & Kumaon Comma & WH & $\begin{array}{l}\text { 12/C1a; } 12 / \\
\text { C2c }\end{array}$ & NR & NA & $2100-4800$ \\
\hline 36 & Sephisa dichroa(Kollar, [1844]) & Western Courtier & $\mathrm{WH} ; \mathrm{CH}$ & $\begin{array}{l}12 / \mathrm{C} 1 \mathrm{a} ; 12 / \\
\mathrm{C} 1 \mathrm{~b} ; 12 / \mathrm{C} 2 \mathrm{c}\end{array}$ & NR & NA & $1500-2740$ \\
\hline 37 & $\begin{array}{l}\text { Symbrenthia niphanda hysudraMoore, } \\
1874\end{array}$ & Bluetail Jester & $\mathrm{WH} ; \mathrm{CH}$ & $\begin{array}{c}\text { 12/C1a; } 12 / \\
\text { C2c }\end{array}$ & $\mathrm{R}$ & Sch-II & $1000-2600$ \\
\hline 38 & Telinga Lepcha lepcha (Moore, 1880) & $\begin{array}{l}\text { West Himalayan } \\
\text { LepchaBushbrown }\end{array}$ & $\mathrm{WH} ; \mathrm{CH}$ & $\begin{array}{l}12 / \mathrm{C} 1 \mathrm{a} ; 12 / \\
\mathrm{C} 2 \mathrm{c} ; 3 \mathrm{C} / \mathrm{C} 2 \mathrm{a}\end{array}$ & NR & NA & $1100-2400$ \\
\hline 39 & Ypthima avanta Moore, [1875] & Jewel Five-ring & $\mathrm{WH} ; \mathrm{CH}$ & 12/C1a & NR & NA & $600-1800$ \\
\hline 40 & $\begin{array}{l}\text { Ypthima hannyngtoni hannyngtoni } \\
\text { Eliot, } 1967\end{array}$ & $\begin{array}{l}\text { Garhwal Large } \\
\text { Branded Five-ring }\end{array}$ & $\mathrm{WH} ; \mathrm{CH}$ & $\begin{array}{c}\text { 12/C1a; } 12 / \\
\text { C1b }\end{array}$ & NR & NA & $2100-2300$ \\
\hline 41 & Ypthima indecora Moore, 1882 & Western Five-ring & $\mathrm{WH} ; \mathrm{CH}$ & $\begin{array}{c}\text { 12/C1a; } 12 / \\
\text { C2c }\end{array}$ & NR & NA & $1300-1700$ \\
\hline 42 & Ypthima kedarnathensis Singh, 2007 & Garhwal Six-ring & $\mathrm{WH} ; \mathrm{CH}$ & $\begin{array}{l}\text { 12/C1a; } 12 / \\
\text { C2c }\end{array}$ & $\mathrm{R}$ & NA & $1600-2200$ \\
\hline D. & LYCAENIDAE & & & & & & \\
\hline 43 & Aricia agestis nazira (Moore, [1866]) & $\begin{array}{l}\text { Orange-bordered } \\
\text { Argus }\end{array}$ & $\mathrm{WH} ; \mathrm{CH}$ & 12/C1a & NR & NA & $1800-2980$ \\
\hline 44 & Chrysozephyrus birupa Moore, 1877 & Fawn Hairstreak & $\mathrm{WH} ; \mathrm{CH}$ & $\begin{array}{c}\text { 12/C1a; } 12 / \\
\text { C2c }\end{array}$ & NR & NA & above 1400 \\
\hline 45 & $\begin{array}{l}\text { Esakiozephyrus icana icana (Moore, } \\
\text { [1875]) }\end{array}$ & Dull-green Hairstreak & $\mathrm{WH} ; \mathrm{CH}$ & $\begin{array}{l}\text { 12/C1a; } 12 / \\
\text { C1d }\end{array}$ & $\mathrm{R}$ & Sch-II & $2000-3300$ \\
\hline 46 & $\begin{array}{l}\text { Euaspa milionia milionia (Hewitson, } \\
\text { [1869]) }\end{array}$ & Water Hairstreak & $\mathrm{WH} ; \mathrm{CH}$ & 12/C1a & NR & NA & $1200-2000$ \\
\hline 47 & $\begin{array}{l}\text { Heliophorus moorei coruscans (Moore, } \\
\text { 1882) }\end{array}$ & Azure Sapphire & $\mathrm{WH} ; \mathrm{CH}$ & $\begin{array}{l}\text { 12/C1a; } 12 / \\
\text { C2c }\end{array}$ & $\mathrm{R}$ & NA & $1300-3000$ \\
\hline 48 & $\begin{array}{l}\text { Pratapa icetas icetas (Hewitson, } \\
\text { [1865]) }\end{array}$ & Dark Blue Royal & $\mathrm{WH} ; \mathrm{CH}$ & $\begin{array}{l}\text { 12/C1a; } 12 / \\
\mathrm{C} 2 \mathrm{~b} ; 12 / \mathrm{C} 2 \mathrm{c}\end{array}$ & $\mathrm{R}$ & Sch-II & $1500-2700$ \\
\hline 49 & $\begin{array}{l}\text { Shizuyaozephyrus ziha (Hewitson, } \\
\text { [1865]) }\end{array}$ & $\begin{array}{l}\text { White-spotted } \\
\text { Hairstreak }\end{array}$ & $\mathrm{WH} ; \mathrm{CH}$ & 12/C1a & $\mathrm{R}$ & Sch-II & $1200-2000$ \\
\hline 50 & $\begin{array}{l}\text { Sinthusa chandrana chandrana } \\
\text { (Moore, 1882) }\end{array}$ & Broad Spark & $\mathrm{WH} ; \mathrm{CH}$ & $\begin{array}{c}\text { 12/C1a; 12/ } \\
\text { C1d; 3C/ } \\
\text { C2a }\end{array}$ & $\mathrm{R}$ & Sch-II & Up to 1820 \\
\hline
\end{tabular}




\begin{tabular}{|c|c|c|c|c|c|c|c|}
\hline & Family/Scientific name & Common name & Distribution & $\begin{array}{c}\text { Associated } \\
\text { forest sub- } \\
\text { type* }\end{array}$ & $\begin{array}{l}\text { Abundance } \\
\text { status }\end{array}$ & WPA status & $\begin{array}{l}\text { Altitudinal } \\
\text { distribution } \\
\text { (m) }\end{array}$ \\
\hline 51 & $\begin{array}{l}\text { Spindasis elimauni formi s (Moore, } \\
\text { 1882) }\end{array}$ & Scarce Shot Silverline & $\mathrm{WH} ; \mathrm{CH}$ & $3 \mathrm{C} / \mathrm{C} 2 \mathrm{a}$ & NR & Sch-II & Up to 2700 \\
\hline 52 & $\begin{array}{l}\text { Thermozephyrus ataxus ataxus } \\
\text { (Westwood, [1851]) }\end{array}$ & Wonderful Hairstreak & $\mathrm{WH} ; \mathrm{CH}$ & $\begin{array}{l}\text { 12/C1a; } 12 / \\
\text { C2c }\end{array}$ & $\mathrm{R}$ & NA & $1800-2400$ \\
\hline $\mathbf{E}$ & RIODINIDAE & & & & & & \\
\hline 53 & $\begin{array}{l}\text { Dodona dipoea nostia Fruhstorfer, } \\
1912\end{array}$ & Lesser Punch & WH & $\begin{array}{c}\text { 12/C1a; } 12 / \\
\text { C2c }\end{array}$ & R & Sch-II & $1800-3000$ \\
\hline 54 & $\begin{array}{l}\text { Dodona ouida phlegra Fruhstorfer, } \\
1914\end{array}$ & Mixed Punch & $\mathrm{WH} ; \mathrm{CH}$ & $\begin{array}{l}\text { 12/C1a; } 12 / \\
\text { C2c }\end{array}$ & NR & NA & $1200-2400$ \\
\hline $\mathbf{F}$ & HESPERIIDAE & & & & & & \\
\hline 55 & $\begin{array}{l}\text { Celaenorrhinus peropero deNicéville, } \\
1889\end{array}$ & $\begin{array}{l}\text { Mussoorie Spotted } \\
\text { Flat }\end{array}$ & WH & 12/C1a & $\mathrm{R}$ & NA & $1500-2000$ \\
\hline 56 & Potanthus dara (Kollar, [1844]) & Himalayan Dart & $\mathrm{WH} ; \mathrm{CH}$ & $\begin{array}{c}\text { 12/C1a; 3C/ } \\
\text { C2a }\end{array}$ & NR & NA & $1830-2590$ \\
\hline 57 & Sovia lucasii (Mabille, 1876) & Lucas's Ace & WH; EH & $9 / \mathrm{c} 1 \mathrm{~b}$ & R & NA & $1800-2000$ \\
\hline 58 & Thoressa aina (de Nicéville, 1889) & Garhwal Ace & $\mathrm{WH} ; \mathrm{CH}$ & 12/C1a & $\mathrm{R}$ & NA & $1370-2800$ \\
\hline
\end{tabular}

WH-Western Himlaya | CH-Central Himalaya |* Forest Sub-type refence Table 2 | Abundance Status (Evans 1932): VR-Very Rare | R-Rare | NR-Not Rare | WPAWildlife (Protection) Act 1972 (Anonymous 2006) | Sch-Schedule listed in WPA1972 (Anon 2006).

Appendix V. Locations of Western Himalayan forest sub-types identified holding butterfly species of conservation priority in the state of Uttarakhand spread over different physiographic zones along the elevation gradient.

\begin{tabular}{|c|c|c|c|c|}
\hline & Physiographic zone & Forest Sub-type & District & Site/village/Reserve Forest \\
\hline \multirow{2}{*}{ A. } & \multirow{2}{*}{$\begin{array}{l}\text { Trans Himalaya } \\
\text { (Above } \\
3600 \mathrm{~m} \text { ) }\end{array}$} & $\begin{array}{l}\text { 14/C1a WestHimalayan Sub-alpine Fir } \\
\text { Forest }\end{array}$ & Chamoli & Ghamsali-Niti Pass \\
\hline & & 14/1S2 Deciduous Sub-alpine Scrub & Chamoli & Mana-Badrinath \& Valley of Flowers NP. \\
\hline \multirow{4}{*}{ B. } & \multirow{4}{*}{$\begin{array}{l}\text { Greater Himalaya } \\
(2400-3600 \mathrm{~m})\end{array}$} & \multirow{3}{*}{ 12/C1a Ban Oak Forest } & Chamoli \& Rudraprayag & $\begin{array}{l}\text { Mandal-Chopta-Duggalbitta-Makkumath- } \\
\text { Kedarnath WS }\end{array}$ \\
\hline & & & Uttarkashi dist & Naitwar-Sankri-Taluka-Osla (Govind WS) \\
\hline & & & Tehri Garhwal & Buddha Kedar-Jhala \\
\hline & & 12/C2c Moist Temperate Deciduous Forest & Chamoli \& Rudra prayag & Mandal-Chopta/Makkumath-Duggalbitta \\
\hline \multirow{7}{*}{ C. } & \multirow{7}{*}{$\begin{array}{l}\text { Lesser Himalaya } \\
(1200-2400 \mathrm{~m})\end{array}$} & \multirow{7}{*}{ 12/C1a Ban Oak Forest } & Dehradun \& Tehri Garhwal & BenogWS-Mussoorie-Kotikimoi-Rotu-ki-beli \\
\hline & & & Dehradun & $\begin{array}{l}\text { Chakrata Cantt-Deoban-Mundali (Chakrata Forest } \\
\text { Division) }\end{array}$ \\
\hline & & & Pauri & Pauri-Talisain-Dudatoli ridge \\
\hline & & & Pithoragarh & Didihat-Thal \\
\hline & & & Nainital & $\begin{array}{l}\text { Naina Devi Conservation reserve-Kilbury-Pangot- } \\
\text { Vinayak Khal }\end{array}$ \\
\hline & & & \multirow{2}{*}{ Almora } & Ranikhet \\
\hline & & & & Binsar WS \\
\hline \multirow{3}{*}{ D. } & \multirow{3}{*}{$\begin{array}{l}\text { Shiwalik-Dun/Bhabar } \\
\text { (Below } 1200 \mathrm{~m} \text { ) }\end{array}$} & \multirow{3}{*}{ 3C/C2a Moist Shiwalik Sal Forest } & \multirow{2}{*}{ Dehradun } & Timli RF-Karvapani RF \\
\hline & & & & Jhajra RF, Chowki Dhaulas-Rikhouli RF \\
\hline & & & Pauri & Rahuthua dhab-Mundipani-Nauri \\
\hline E. & $\begin{array}{l}\text { Tarai } \\
(100-350 m)\end{array}$ & 3C/C2c Moist Terai Sal Forest & Nainital & Chorgalia-Jolasal-Senapani (Nandhaur WS) \\
\hline
\end{tabular}



Dr. John Noyes, Natural History Museum, London, UK

Dr. Albert G. Orr, Griffith University, Nathan, Australia

Dr. Sameer Padhye, Katholieke Universiteit Leuven, Belgium

Dr. Nancy van der Poorten, Toronto, Canada

Dr. Kareen Schnabel, NIWA, Wellington, New Zealand

Dr. R.M. Sharma, (Retd.) Scientist, Zoological Survey of India, Pune, India

Dr. Manju Siliwal, WILD, Coimbatore, Tamil Nadu, India

Dr. G.P. Sinha, Botanical Survey of India, Allahabad, India

Dr. K.A. Subramanian, Zoological Survey of India, New Alipore, Kolkata, India

Dr. P.M. Sureshan, Zoological Survey of India, Kozhikode, Kerala, India

Dr. R. Varatharajan, Manipur University, Imphal, Manipur, India

Dr. Eduard Vives, Museu de Ciències Naturals de Barcelona, Terrassa, Spain

Dr. James Young, Hong Kong Lepidopterists' Society, Hong Kong

Dr. R. Sundararaj, Institute of Wood Science \& Technology, Bengaluru, India

Dr. M. Nithyanandan, Environmental Department, La Ala Al Kuwait Real Estate. Co. K.S.C.,

Kuwait

Dr. Himender Bharti, Punjabi University, Punjab, India

Mr. Purnendu Roy, London, UK

Dr. Saito Motoki, The Butterfly Society of Japan, Tokyo, Japan

Dr. Sanjay Sondhi, TITLI TRUST, Kalpavriksh, Dehradun, India

Dr. Nguyen Thi Phuong Lien, Vietnam Academy of Science and Technology, Hanoi, Vietnam

Dr. Nitin Kulkarni, Tropical Research Institute, Jabalpur, India

Dr. Robin Wen Jiang Ngiam, National Parks Board, Singapore

Dr. Lional Monod, Natural History Museum of Geneva, Genève, Switzerland.

Dr. Asheesh Shivam, Nehru Gram Bharti University, Allahabad, India

Dr. Rosana Moreira da Rocha, Universidade Federal do Paraná, Curitiba, Brasi

Dr. Kurt R. Arnold, North Dakota State University, Saxony, Germany

Dr. James M. Carpenter, American Museum of Natural History, New York, USA

Dr. David M. Claborn, Missouri State University, Springfield, USA

Dr. Kareen Schnabel, Marine Biologist, Wellington, New Zealand

Dr. Amazonas Chagas Júnior, Universidade Federal de Mato Grosso, Cuiabá, Brasil

Mr. Monsoon Jyoti Gogoi, Assam University, Silchar, Assam, India

Dr. Heo Chong Chin, Universiti Teknologi MARA (UiTM), Selangor, Malaysia

Dr. R.J. Shiel, University of Adelaide, SA 5005, Australia

Dr. Siddharth Kulkarni, The George Washington University, Washington, USA

Dr. Priyadarsanan Dharma Rajan, ATREE, Bengaluru, India

Dr. Phil Alderslade, CSIRO Marine And Atmospheric Research, Hobart, Australia

Dr. John E.N. Veron, Coral Reef Research, Townsville, Australia

Dr. Daniel Whitmore, State Museum of Natural History Stuttgart, Rosenstein, Germany.

Dr. Yu-Feng Hsu, National Taiwan Normal University, Taipei City, Taiwan

Dr. Keith V. Wolfe, Antioch, California, USA

Dr. Siddharth Kulkarni, The Hormiga Lab, The George Washington University, Washington,

D.C., USA

Dr. Tomas Ditrich, Faculty of Education, University of South Bohemia in Ceske

Budejovice, Czech Republic

Dr. Mihaly Foldvari, Natural History Museum, University of Oslo, Norway

Dr. V.P. Uniyal, Wildlife Institute of India, Dehradun, Uttarakhand 248001, India

Dr. John T.D. Caleb, Zoological Survey of India, Kolkata, West Bengal, India

Dr. Priyadarsanan Dharma Rajan, Ashoka Trust for Research in Ecology and the Environment

(ATREE), Royal Enclave, Bangalore, Karnataka, India

\section{Fishes}

Dr. Neelesh Dahanukar, IISER, Pune, Maharashtra, India

Dr. Topiltzin Contreras MacBeath, Universidad Autónoma del estado de Morelos, México

Dr. Heok Hee Ng, National University of Singapore, Science Drive, Singapore

Dr. Rajeev Raghavan, St. Albert's College, Kochi, Kerala, India

Dr. Robert D. Sluka, Chiltern Gateway Project, A Rocha UK, Southall, Middlesex, UK

Dr. E. Vivekanandan, Central Marine Fisheries Research Institute, Chennai, India

Dr. Davor Zanella, University of Zagreb, Zagreb, Croatia

Dr. A. Biju Kumar, University of Kerala, Thiruvananthapuram, Kerala, India

Dr. Akhilesh K.V., ICAR-Central Marine Fisheries Research Institute, Mumbai Research

Centre, Mumbai, Maharashtra, India

Dr. J.A. Johnson, Wildlife Institute of India, Dehradun, Uttarakhand, India

Amphibians

Dr. Sushil K. Dutta, Indian Institute of Science, Bengaluru, Karnataka, India

Dr. Annemarie Ohler, Muséum national d'Histoire naturelle, Paris, France

\section{Reptiles}

Dr. Gernot Vogel, Heidelberg, Germany

Dr. Raju Vyas, Vadodara, Gujarat, India

Dr. Pritpal S. Soorae, Environment Agency, Abu Dubai, UAE.

Prof. Dr. Wayne J. Fuller, Near East University, Mersin, Turkey

Prof. Chandrashekher U. Rivonker, Goa University, Taleigao Plateau, Goa. India

Dr. S.R. Ganesh, Chennai Snake Park, Chennai, Tamil Nadu, India

Dr. Himansu Sekhar Das, Terrestrial \& Marine Biodiversity, Abu Dhabi, UAE
Birds

Dr. Hem Sagar Baral, Charles Sturt University, NSW Australia

Dr. Chris Bowden, Royal Society for the Protection of Birds, Sandy, UK

Dr. Priya Davidar, Pondicherry University, Kalapet, Puducherry, India

Dr. J.W. Duckworth, IUCN SSC, Bath, UK

Dr. Rajah Jayapal, SACON, Coimbatore, Tamil Nadu, India

Dr. Rajiv S. Kalsi, M.L.N. College, Yamuna Nagar, Haryana, India

Dr. V. Santharam, Rishi Valley Education Centre, Chittoor Dt., Andhra Pradesh, India

Dr. S. Balachandran, Bombay Natural History Society, Mumbai, India

Mr. J. Praveen, Bengaluru, India

Dr. C. Srinivasulu, Osmania University, Hyderabad, India

Dr. K.S. Gopi Sundar, International Crane Foundation, Baraboo, USA

Dr. Gombobaatar Sundev, Professor of Ornithology, Ulaanbaatar, Mongolia

Prof. Reuven Yosef, International Birding \& Research Centre, Eilat, Israel

Dr. Taej Mundkur, Wetlands International, Wageningen, The Netherlands

Dr. Carol Inskipp, Bishop Auckland Co., Durham, UK

Dr. Tim Inskipp, Bishop Auckland Co, Durham, UK

Dr. V. Gokula, National College, Tiruchirappalli, Tamil Nadu, India

Dr. Arkady Lelej, Russian Academy of Sciences, Vladivostok, Russia

Dr. Simon Dowell, Science Director, Chester Zoo, UK

Dr. Mário Gabriel Santiago dos Santos, Universidade de Trás-os-Montes e Alto Douro,

Quinta de Prados, Vila Real, Portugal

Dr. Grant Connette, Smithsonian Institution, Royal, VA, USA

Dr. M. Zafar-ul Islam, Prince Saud Al Faisal Wildlife Research Center, Taif, Saudi Arabia

Mammals

Dr. Giovanni Amori, CNR - Institute of Ecosystem Studies, Rome, Italy

Dr. Anwaruddin Chowdhury, Guwahati, India

Dr. David Mallon, Zoological Society of London, UK

Dr. Shomita Mukherjee, SACON, Coimbatore, Tamil Nadu, India

Dr. Angie Appel, Wild Cat Network, Germany

Dr. P.O. Nameer, Kerala Agricultural University, Thrissur, Kerala, India

Dr. Ian Redmond, UNEP Convention on Migratory Species, Lansdown, UK

Dr. Heidi S. Riddle, Riddle's Elephant and Wildlife Sanctuary, Arkansas, USA

Dr. Karin Schwartz, George Mason University, Fairfax, Virginia.

Dr. Lala A.K. Singh, Bhubaneswar, Orissa, India

Dr. Mewa Singh, Mysore University, Mysore, India

Dr. Paul Racey, University of Exeter, Devon, UK

Dr. Honnavalli N. Kumara, SACON, Anaikatty P.O., Coimbatore, Tamil Nadu, India

Dr. Nishith Dharaiya, HNG University, Patan, Gujarat, India

Dr. Spartaco Gippoliti, Socio Onorario Società Italiana per la Storia della Fauna "Giuseppe

Altobello", Rome, Italy

Dr. Justus Joshua, Green Future Foundation, Tiruchirapalli, Tamil Nadu, India

Dr. H. Raghuram, The American College, Madurai, Tamil Nadu, India

Dr. Paul Bates, Harison Institute, Kent, UK

Dr. Jim Sanderson, Small Wild Cat Conservation Foundation, Hartford, USA

Dr. Dan Challender, University of Kent, Canterbury, UK

Dr. David Mallon, Manchester Metropolitan University, Derbyshire, UK

Dr. Brian L. Cypher, California State University-Stanislaus, Bakersfield, CA

Dr. S.S. Talmale, Zoological Survey of India, Pune, Maharashtra, India

Prof. Karan Bahadur Shah, Budhanilakantha Municipality, Kathmandu, Nepal

Dr. Susan Cheyne, Borneo Nature Foundation International, Palangkaraja, Indonesia

Dr. Hemanta Kafley, Wildlife Sciences, Tarleton State University, Texas, USA

\section{Other Disciplines}

Dr. Aniruddha Belsare, Columbia MO 65203, USA (Veterinary)

Dr. Mandar S. Paingankar, University of Pune, Pune, Maharashtra, India (Molecular)

Dr. Jack Tordoff, Critical Ecosystem Partnership Fund, Arlington, USA (Communities)

Dr. Ulrike Streicher, University of Oregon, Eugene, USA (Veterinary)

Dr. Hari Balasubramanian, EcoAdvisors, Nova Scotia, Canada (Communities)

Dr. Rayanna Hellem Santos Bezerra, Universidade Federal de Sergipe, São Cristóvão, Brazil

Dr. Jamie R. Wood, Landcare Research, Canterbury, New Zealand

Dr. Wendy Collinson-Jonker, Endangered Wildlife Trust, Gauteng, South Africa

Dr. Rajeshkumar G. Jani, Anand Agricultural University, Anand, Gujarat, India

Dr. O.N. Tiwari, Senior Scientist, ICAR-Indian Agricultural Research Institute (IARI), New

Delhi, India

Dr. L.D. Singla, Guru Angad Dev Veterinary and Animal Sciences University, Ludhiana, India

Dr. Rupika S. Rajakaruna, University of Peradeniya, Peradeniya, Sri Lanka

Dr. Bahar Baviskar, Wild-CER, Nagpur, Maharashtra 440013, India

Reviewers 2018-2020

Due to pausity of space, the list of reviewers for $2018-2020$ is available online.

The opinions expressed by the authors do not reflect the views of the Journal of Threatened Taxa, Wildlife Information Liaison Development Society, Zoo Outreach Organization, or any of the partners. The journal, the publisher, the host, and the partners are not responsible for the accuracy of the political boundaries shown in the maps by the authors.

Journal of Threatened Taxa is indexed/abstracted in Bibliography of Systematic Mycology, Biological Abstracts, BIOSIS Previews, CAB Abstracts, EBSCO, Google Scholar, Index Copernicus, Index Fungorum, JournalSeek, National Academy of Agricultural Sciences, NewJour, OCLC WorldCat, SCOPUS, Stanford University Libraries, Virtual Library of Biology, Zoological Records.

NAAS rating (India) 5.64
Print copies of the Journal are available at cost. Write to:

The Managing Editor, JoTT,

c/o Wildlife Information Liaison Development Society,

No. 12, Thiruvannamalai Nagar, Saravanampatti - Kalapatti Road,

Saravanampatti, Coimbatore, Tamil Nadu 641035, India

ravi@threatenedtaxa.org 


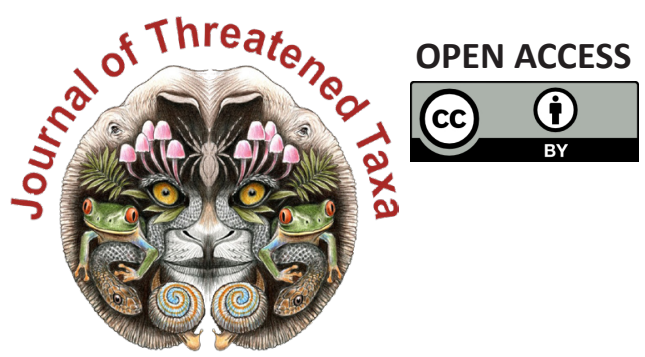

www.threatenedtaxa.org

The Journal of Threatened Taxa (JoTT) is dedicated to building evidence for conservation globally by publishing peer-reviewed articles online every month at a reasonably rapid rate at www.threatenedtaxa.org. All articles published in JoTT are registered under Creative Commons Attribution 4.0 International License unless otherwise mentioned. JoTT allows allows unrestricted use, reproduction, and distribution of articles in any medium by providing adequate credit to the author(s) and the source of publication.

\section{ISSN $0974-7907$ (Online) | ISSN $0974-7893$ (Print)}

\section{January 2022 | Vol. 14 | No. 1 | Pages: 20311-20538 \\ Date of Publication: 26 January 2022 (Online \& Print) DOI: 10.11609/jott.2022.14.1.20311-20538}

Articles

Estimating the completeness of orchid checklists and atlases: a case study from southern Italy

- Antonio Croce, Pp. 20311-20322

A floristic survey across three coniferous forests of Kashmir Himalaya, India - a checklist

- Ashaq Ahmad Dar, Akhtar Hussain Malik \& Narayanaswamy Parthasarathy, Pp. 20323-20345

Associations of butterflies across different forest types in Uttarakhand, western Himalaya, India: implications for conservation planning

- Arun Pratap Singh, Pp. 20346-20370

Comparison of bird diversity in protected and non-protected wetlands of western lowland of Nepal

- Jagan Nath Adhikari, Janak Raj Khatiwada, Dipendra Adhikari, Suman Sapkota, Bishnu Prasad Bhattarai, Deepak Rijal \& Lila Nath Sharma, Pp. 20371-20386

Local hunting practices and perceptions regarding the distribution and ecological role of the Large Flying Fox (Chiroptera: Pteropodidae: Pteropus vampyrus) in western Sarawak, Malaysian Borneo

- Jayasilan Mohd-Azlan, Joon Yee Yong, Nabila Norshuhadah Mohd Hazzrol, Philovenny Pengiran, Arianti Atong \& Sheema Abdul Aziz, Pp. 20387-20399

\section{Communications}

Macrolichens of Mathikettan Shola National Park, Western Ghats: a preliminary investigation with some new records

- Aswathi Anilkumar, Stephen Sequeira, Arun Christy \& S.M. Arsha, Pp. 20400-20405

New distribution record of globally threatened Ocean Turf Grass Halophila beccarii Ascherson, 1871 from the North Andaman Islands highlights the importance of seagrass exploratory surveys

- Swapnali Gole, Prasad Gaidhani, Srabani Bose, Anant Pande, Jeyaraj Antony Johnson \& Kuppusamy Sivakumar, Pp. 20406-20412

An inventory of new orchid (Orchidaceae) records from Kozhikode, Kerala, India - M. Sulaiman, C. Murugan \& M.U. Sharief, Pp. 20413-20425

Abundance and spatial distribution analyses of Stemonoporus moonii Thwaites (Dipterocarpaceae) - a critically endangered species endemic to Sri Lanka - K.A.M.R.P. Atapattu, H.D.D.C.K. Perera, H.S. Kathriarachchi \& A.R. Gunawardena, Pp. 20426-20432

Plant diversity of Point Calimere Wildlife Sanctuary and fodder species grazed by the Blackbuck Antilope cervicapra L.

- Ashutosh Kumar Upadhyay, A. Andrew Emmanuel, Ansa Sarah Varghese \&

D. Narasimhan, Pp. 20433-20443

Raptors observed (1983-2016) in National Chambal Gharial Sanctuary: semi-arid biogeographic region suggestions for parametric studies on ecological continuity in Khathiar-Gir Ecoregion, India

- L.A.K. Singh, R.K. Sharma \& Udayan Rao Pawar, Pp. 20444-20460

Nesting success of Sharpe's Longclaw (Macronyx sharpei Jackson, 1904) around the grasslands of lake Ol'bolossat Nyandarua, Kenya

- Hamisi Ann Risper, Charles M. Warui \& Peter Njoroge, Pp. 20461-20468

Population, distribution and diet composition of Smooth-coated Otter Lutrogale perspicillata Geoffroy, 1826 in Hosur and Dharmapuri Forest Divisions, India - Nagarajan Baskaran, Raman Sivaraj Sundarraj \& Raveendranathanpillai Sanil, Pp. 20469-20477

Utilization of home garden crops by primates and current status of human-primate interface at Galigamuwa Divisional Secretariat Division in Kegalle District, Sri Lanka

- Charmalie Anuradhie Dona Nahallage, Dahanakge Ayesha Madushani Dasanayake, Dilan Thisaru Hewamanna \& Dissanayakalage Tharaka Harshani Ananda, Pp. 2047820487
Revival of Eastern Swamp Deer Rucervus duvaucelii ranjitsinhi (Groves, 1982) in Manas National Park of Assam, India

- Nazrul Islam, Aftab Ahmed, Rathin Barman, Sanatan Deka, Bhaskar Choudhury, Prasanta Kumar Saikia \& Jyotishman Deka, Pp. 20488-20493

Trypanosoma evansi infection in a captive Indian Wolf Canis lupus pallipes - molecular diagnosis and therapy

- Manojita Dash, Sarat Kumar Sahu, Santosh Kumar Gupta, Niranjana Sahoo \& Debarat Mohapatra, Pp. 20494-20499

View Point

COVID-19 and civil unrest undoing steady gains in karst conservation and herpetological research in Myanmar, and an impediment to progress - Evan S.H. Quah, Lee L. Grismer, Perry L. Wood, Jr., Aung Lin \& Myint Kyaw Thura, Pp. 20500-20502

\section{Short Communications}

Morphological characterization and mt DNA barcode of a tiger moth species, Asota ficus (Fabricius, 1775) (Lepidoptera: Noctuoidea: Erebidae: Aganainae) from India - Aparna Sureshchandra Kalawate, K.P. Dinesh \& A. Shabnam, Pp. 20503-20510

Distribution of Smooth-coated Otters Lutrogale perspicillata (Mammalia: Carnivora: Mustelidae): in Ratnagiri, Maharashtra, India

- Swanand Patil \& Kranti Yardi, Pp. 20511-20516

Wildlife at the crossroads: wild animal road kills due to vehicular collision on a mountainous highway in northwestern Himalayan region

- Muzaffar A. Kichloo, Asha Sohil \& Neeraj Sharma, Pp. 20517-20522

Notes

Robiquetia gracilis (Lindl.) Garay-a new record to the flora of Anamalai Hills, Tami Nadu, India

- B. Subbaiyan, V. Ganesan, P.R. Nimal Kumar \& S. Thangaraj Panneerselvam, Pp. 20523-20525

Ipomoea laxiflora H.J. Chowdhery \& Debta (Convolvulaceae): new records for the Western Ghats and semiarid regions

- Sachin M. Patil, Ajit M. Vasava, Vinay M. Raole \& Kishore S. Rajput, Pp. 20526-20529

Counting the cost: high demand puts Bunium persicum (Boiss.) B.Fedtsch. in jeopardy

- Monika Sharma, Manisha Mathela, Rupali Sharma, Himanshu Bargali, Gurinderjit S Goraya \& Amit Kumar, Pp. 20530-20533

First record of Parasitic Jaeger Stercorarius parasiticus (Aves: Charadriiformes: Stercorariidae) from inland freshwater Inle Lake, Myanmar

- Sai Sein Lin Oo, Myint Kyaw, L.C.K. Yun, Min Zaw Tun, Yar Zar Lay Naung, Soe Naing Aye \& Swen C. Renner, Pp. 20534-20536

\section{Book Review}

Capparis of India

- V. Sampath Kumar, Pp. 20537-20538
Publisher \& Host
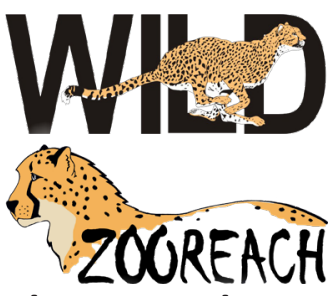

Threatened Taxa 